\title{
Lowland forest butterflies of the Sankosh River catchment, Bhutan
}

\author{
Arun P. Singh \\ Assam 785001, India \\ Email: ranoteaps@gmail.com,singhap@icfre.org \\ Date of publication (online): 10 October 2012 \\ Date of publication (print): 10 October 2012 \\ ISSN $0974-7907$ (online) | 0974-7893 (print) \\ Editor: Ullasa Kodandaramaiah \\ Manuscript details: \\ Ms \# 02625 \\ Received 12 November 2010 \\ Final received 17 July 2012 \\ Finally accepted 20 August 2012
}

Ecology and Biodiversity Conservation Division, Rain Forest Research Institute (ICFRE), P.O. Box no. 136, Deovan, Sotai, Jorhat,
Citation: Singh, A.P. (2012). Lowland forest butterflies of the Sankosh River catchment, Bhutan. Journal of Threatened Taxa 4(12): 3085-3102.

Copyright: (c) Arun P. Singh 2012. Creative Commons Attribution 3.0 Unported License. JoTT allows unrestricted use of this article in any medium for non-profit purposes, reproduction and distribution by providing adequate credit to the authors and the source of publication.

Author Details: ARUN P. SINGH works on the conservation of biodiversity of Himalaya with special reference to butterflies and birds since 18 years. His research works include ecology, taxonomy, and environmental impact assessment (EIA) studies. Presently, he heads the Ecology and Biodiversity Conservation Division, Rain Forest Research Institute (ICFRE), Jorhat, Assam.

Acknowledgements: This study was part of the EIA of the proposed Indo-Bhutan Sankosh Hydro Electric Power project at Kerabari, being carried out by the Indian Council of Forestry Research and Education (ICFRE), Dehradun. The author is thankful to DG (ICFRE), DDG (Extension, ICFRE) \& ADG and Sudhir Kumar project manager (EIA Division, ICFRE), and Director, FRI, India, and Department of Energy and Range Officer, Kalikhola, Forest Department of the Royal Government of Bhutan for providing the necessary facilities to carry out this study.

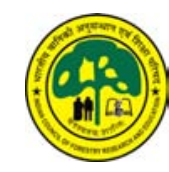

\section{(c) (1) (ே)}

OPEN ACGESS | FREE DOWNLOAD
Abstract: This paper provides information on butterflies of the lowland forests of Bhutan for the first time. As a part of the biodiversity impact assessment for the proposed Sankosh hydroelectric power project, a survey was carried out along the Sankosh River catchment to study the butterfly diversity. The aim of the study was to identify species of conservation priority, their seasonality and to know the butterfly diversity potential of the area. Surveys were carried out during five different seasons (winter, spring, pre-monsoon, monsoon, post-monsoon) lasting 18 days from January 2009 to March 2010. Pollard walk method was used to assess the diversity on four-line transects within 10-12 km radius of the proposed dam site. Two hundred and thirteen species, including 22 papilionids, were thus sampled. Eleven species amongst these are listed in Schedules I and II of the Indian Wildlife (Protection) Act, 1972, of which 10 taxa (Pareronia avatar avatar, Nacaduba pactolus continentalis, Porostas aluta coelestis, Elymnias vasudeva vasudeva, Mycalesis mestra retus, Melanitis zitenius zitenius, Charaxes marmax, Athyma ranga ranga, Neptis manasa manasa and Neptis soma soma) are of conservation priority as they are 'rare' in occurrence across their distribution range in the region. The maximum number of species (128) were recorded during the spring season (March) and lowest (66) during July (monsoon). The seasonal pattern of variation in diversity was very typical of the pattern found in other areas of the lower foothills and adjoining plains of the Himalaya. Relative abundances of butterflies during spring varied significantly $(p<0.05)$ as compared to winter, pre-monsoon and post-monsoon seasons. However, species composition changed with every season as Sorensen's similarity index varied between 0.3076 to 0.5656 . All these findings suggest that the lowland forests of Bhutan hold a rich and unique diversity of butterflies during every season of the year thus having a good potential for ecotourism. Establishment of a butterfly conservatory and park as a 'biodiversity offset' for conservation of 'rare' species along with more field surveys in the study area will be a way forward along with the present work to bridge the exisiting gaps in knowledge on butterflies of the subtropical lowland forests of the Himalayas.

Keywords: Indian Wildlife Protection Act 1972, Phibsoo Wildlife Sanctuary, rare species, seasonality, Shorea robusta, Simpsons index, Sorensen's index, sub-tropical.

\section{INTRODUCTION}

Reducing the impact of large dams on biodiversity calls for knowing where species, ecosystems and ecological functions are located. Lack of that information is one of the serious impediments and is a result of poor support for biological surveys, research and academic work on taxonomy and ecology. IUCN, UNEP and WCD recommendations on dams and biodiversity (McAllister et al. 2001), highlight the need to avoid biodiversity 'hotspots' and 'hot' portions of gradients. The avoidance of areas rich in species and endemic species needs to be given high priority in selection criteria. That includes both, choosing watersheds and sites within watersheds, and taking into account 'hotspots' and gradients in biodiversity. Besides, the recommendations also highlight the need to carry out research on biodiversity as our knowledge on biodiversity is incomplete and geographic distributions are poorly documented 
(McAllister et al. 2001). The environmental impact of large dams on lower groups of organisms, such as insects, is hardly ever studied for loss of wildlife in India (Mishra 2009).

According to Conservation International, Bhutan forms a part of the 'Eastern Himalaya Biodiversity Hotspot' which is one of the 34 biodiversity hotspots of the world today (www.biodiversityhotspots.org/). A home for over 50 species of rhododendrons, large numbers of orchids (http://www.bhutan2008.bt/en/ node/276), Bhutan is also one of the 221 global endemic bird areas with over 770 avian species (Inskipp et al. 1999). Bhutan along with northeastern India are the meeting place of the central Asian and Chinese subdivisions of the Palaeartic region with the peninsular Indian and Malayan subdivisions of the oriental region and are therefore considered very rich areas in terms of butterflies. With incredible variations, from subtropical to alpine along the altitudinal gradient (100-4,200 m), Bhutan presents a large variety of habitats for butterflies. The adjoining state of Sikkim which lies west of Bhutan in India has over 689 species (Haribal 1992). Besides, 962 taxa of butterflies have been identified from northeastern India from Sikkim, Assam, Manipur; Meghalaya, Nagaland Mizoram and northern Myanmar (Evans 1932). On the other hand Wynter-Byth (1957) gives a figure of 835 species of butterflies from northeastern India including Sikkim, Bhutan and Assam up to Chittagong. However, information on butterflies of Bhutan as such is scanty. A booklet published by van der Poel \& Wangchuk (2007) on butterflies of the Bhutan mountains, hills and valleys between 800-3,000 m lists only 136 species from the country. van der Poel \& Wangchuk (2007) does not include butterflies from subtropical low land forests of Bhutan lying below 300m, which are contiguous with forests in India and are considered rich in terms of biodiversity. One estimate for Bhutan puts the figure between $800-900$ species with the largest number being found in the 'subtropical' zone (van der Poel \& Wangchuk 2007).

The present work on butterflies is part of the environment impact assessment studies undertaken on biodiversity of the influence (downstream) and impact zone (upstream) for a proposed dam to be built by India, near Kerabari (26044'93N \& 89055'55E), in Bhutan, under the Sankosh Hydro-electric Power Project (Images $1 \& 2$ ).

\section{MATERIAL AND METHODS}

\section{Study Area}

The study area falls in the subtropical forests in the southwesternmost part of Bhutan in the southcentral Dzongkhag (Sarpang District). These forests are broadly classified as semievergreen but vary from almost totally deciduous on exposed dry slopes to almost totally evergreen in the forest valleys. Adjacent to and east of the study area lies the Phibsoo Wildlife Sanctuary. The sanctuary covers an area of $265 \mathrm{~km}^{2}$ of unique dry shorea forest ecosystem and conserves tropical fauna such as the Tiger Panthera tigris, Elephant Elephas maximus, Gaur Bos gaurus, Golden Langur Trachypithecus geei, Indian Wild Dog or Dhole Cuon alpinus, Grey Peacock Pheasant Polyplectron bicalcaratum, Rufous-necked Hornbill Aceros nipalensis, Wreathed Hornbill A. undulatus, Great Hornbill Buceros bicornis and is the only protected area in Bhutan having Chital Deer Axis axis and natural sal forests. Phibsoo Wildlife Sanctuary touches its border with India and is linked on its southwestern end to the Buxa Tiger Reserve in West Bengal, India ca. $100 \mathrm{~km}$ to the south-east of the study site, in India, lies the Ripu-Chirang Wildlife Sanctuary (RCWF; 89 $55^{\prime}-90^{0} 30^{\prime} \mathrm{E} \& 2^{0} 15^{\prime}-26^{0} 35^{\prime} \mathrm{N}$ ) in western Assam which is a transitional zone between Manas Tiger Reserve in the east and Buxa Tiger Reserve in the west. About 300 species of butterflies have been recorded from RCWF including the rare Yellow-crested Spangle Papilio elephenor Doubleday, 1886 and Moore's Cupid Shijimia moorei Leech, 1889 (Choudhury 2010), although the list has not been given.

\section{Sampling}

Five sampling surveys were carried out during 7-9 January 2009 (winter), 13-14; 17-19 May 2009 (pre-monsoon), 11-13 July 2009 (monsoon), 26-28 November 2009 (post-monsoon) and 19-22 March 2010 (spring) in the study area (Images 3-8). In January the day temperature and relative humidity (11:30-15:30 hr) varied between $23.6-27.8{ }^{\circ} \mathrm{C}$ and 57.4-58.4\%, respectively, with days being short. During March relative humidity varied between 57.1$60.1 \%$ and day temperature between $33.4-34.2{ }^{\circ} \mathrm{C}$. In May the weather was hot and dry while during July (monsoon) the whole area remained under cloud cover 


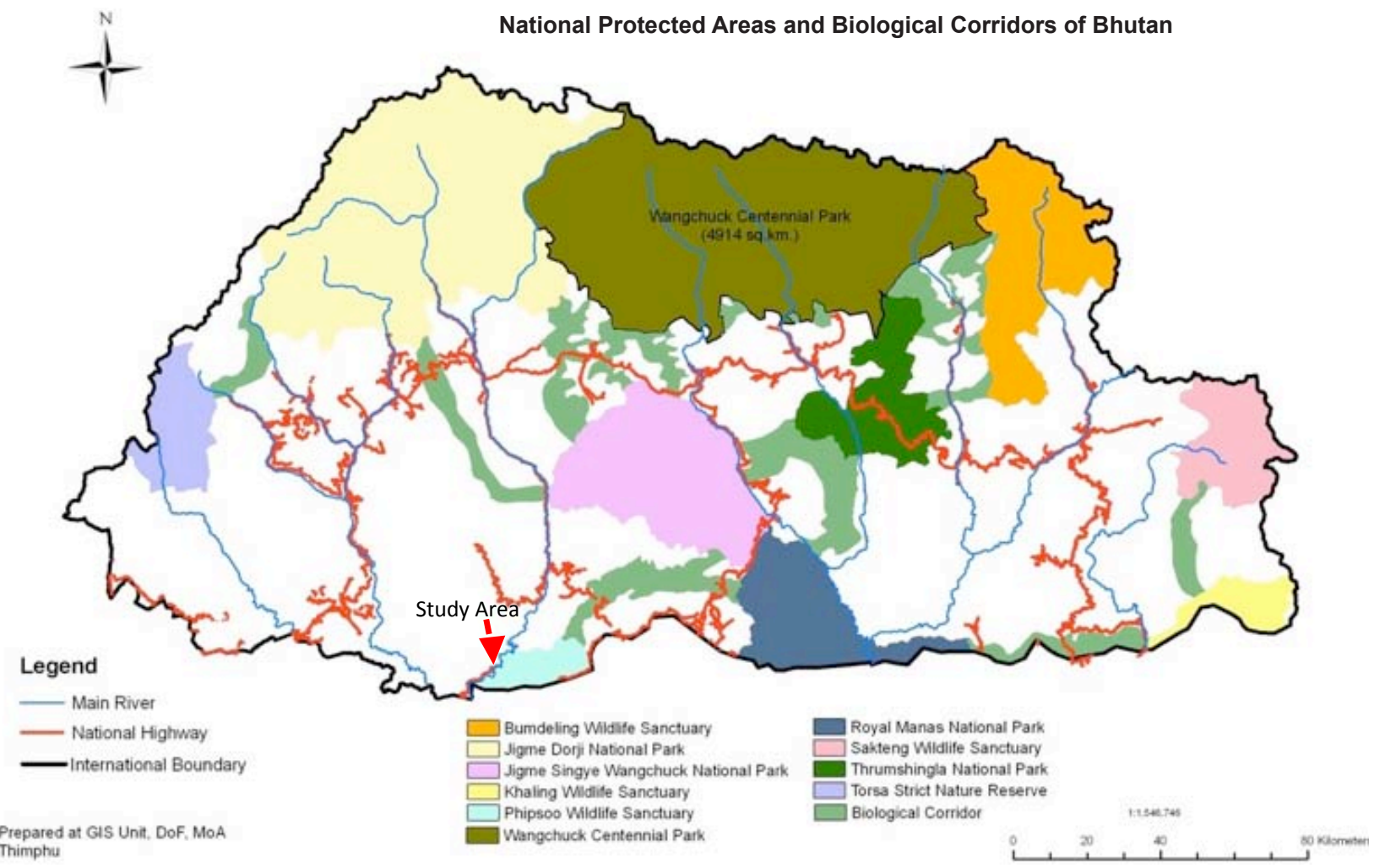

Image 1. Map of Bhutan depicting the location of protected areas and the study area bordering India

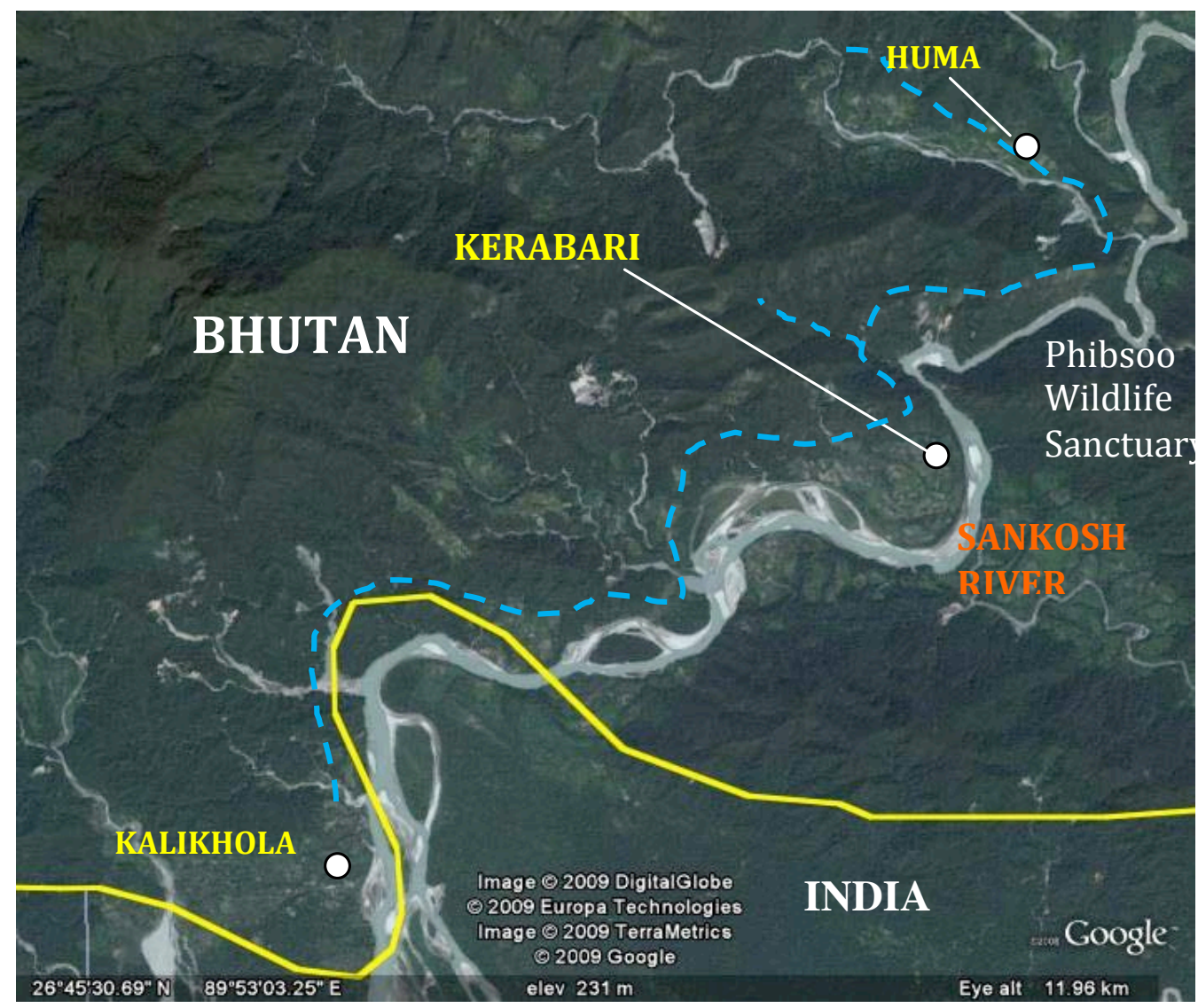

Image 2. Location of study sites, the road from Kalikhola to Kerabari and the foot trail beyond up to Huma Village, marked in blue, along which the sampling surveys were undertaken along the right bank of Sankosh River. 


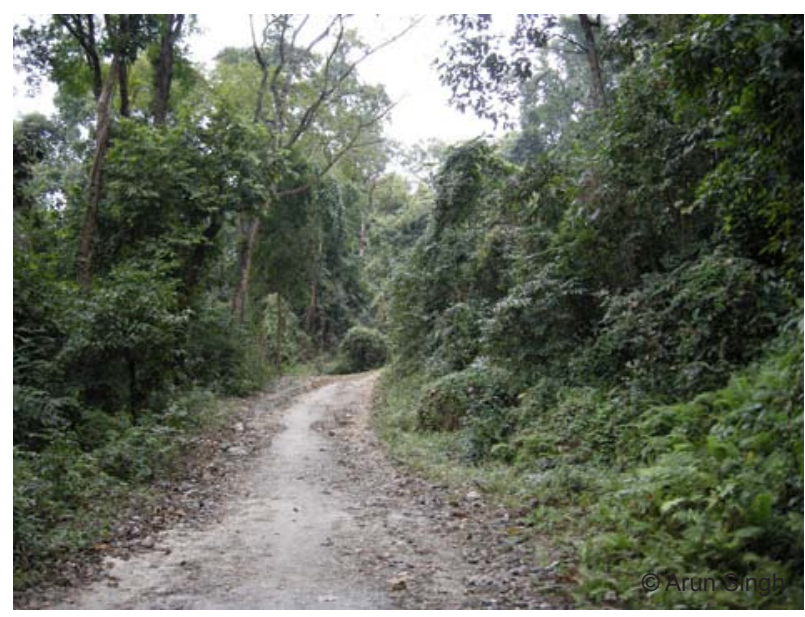

Image 3. Low forest habitat during the monsoon season (July) near Kalikhola

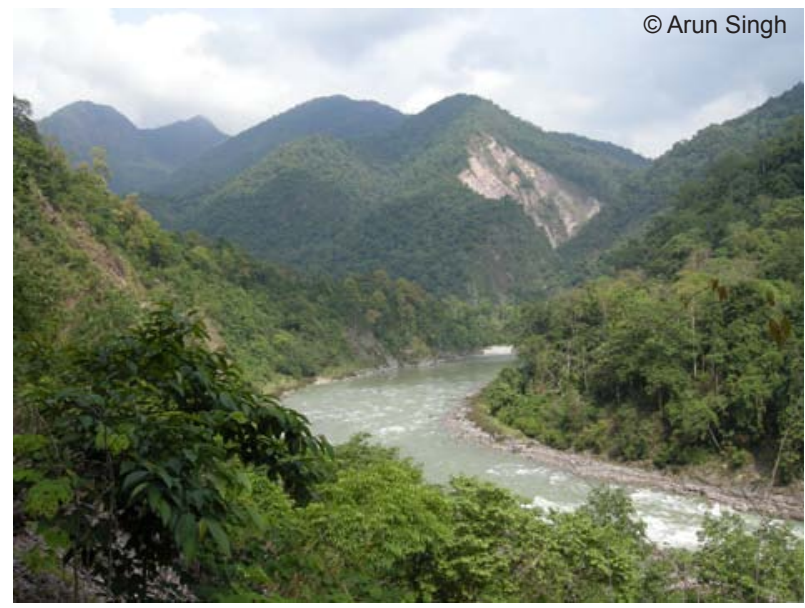

Image 5. Sankosh River flowing further up from the dam site close to Huma

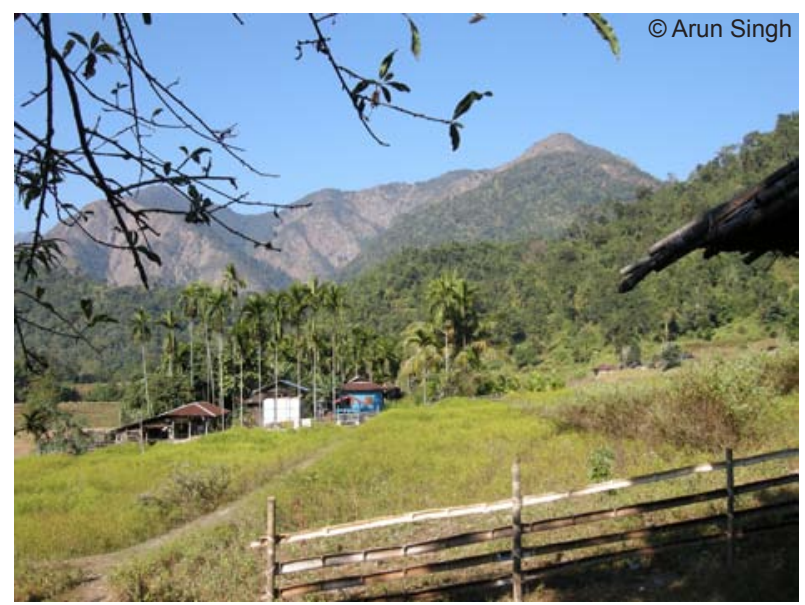

Image 7. Huma Village

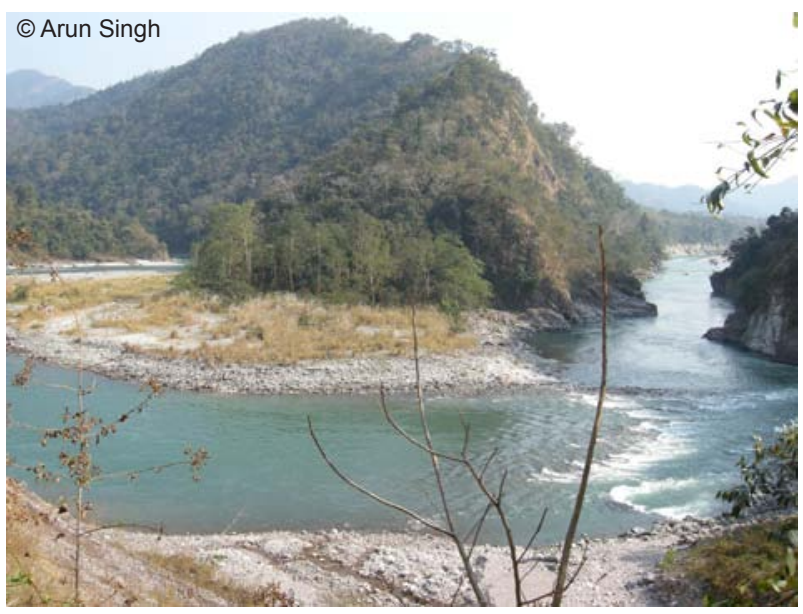

Image 4. Sankosh River flowing through Kalikhola-Huma Khola transect near dam site during winter (January)

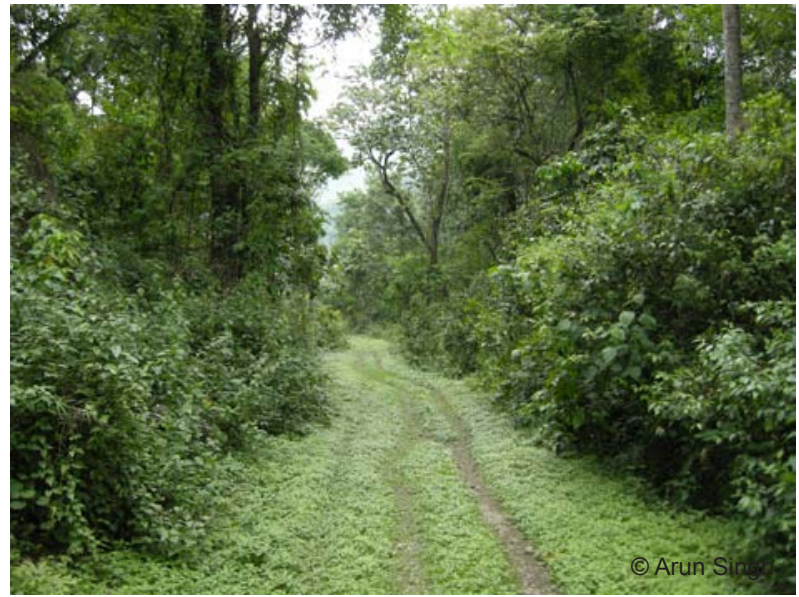

Image 6. Low forest habitat during pre-monsoon season (May)

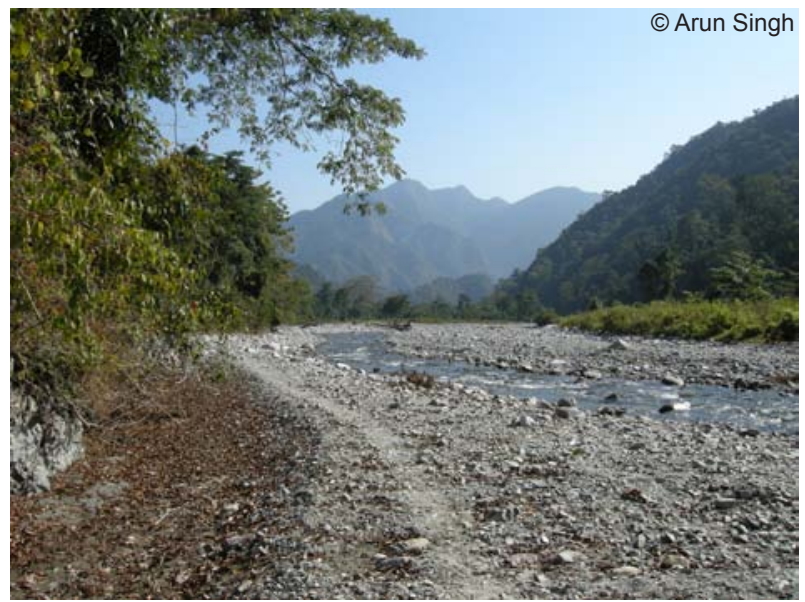

Image 8. Hama Khola (riverlet) during winter (January) 
with high relative humidity ( $83-90 \%$ ) and temperature $\left(30.3-32 \cdot 1{ }^{\circ} \mathrm{C}\right)$. At this time rain drizzled intermittently throughout the day while all the road network between Kalikhola (26 $\left.44^{\circ} 20 \mathrm{~N} \& 89^{\circ} 51^{\prime} 25 \mathrm{E}\right)$ and Kerabari was washed out at places by running seasonal streams. During November the weather was cool and dry (relative humidity $61-62 \%$; temperature $26-27{ }^{\circ} \mathrm{C}$ ) the weather at this time being more comfortable to work in and the road network is also restored.

Transect walks were undertaken along the road that links Kalikhola Village located on the Indian border to Kerabari Village $(15 \mathrm{~km})$ and then further on a foot trail linking Kerabari-Huma Semal Village $(6 \mathrm{~km})$ along the Sankosh River and finally $5 \mathrm{~km}$ further north upstream from Huma Khola on a foot trail. All the sampling sites lay on the right bank of the river Sankosh between 118-220 $\mathrm{m}$ and 26044'21"-26047'69' $\mathrm{N}$ \& 89051'25-89'56'05'E. 'Pollard Walk' method used for sampling butterflies was carried out throughout the day from morning (10:00 hr) until sunset (17:00-18:00 hr), but the total number of sampling hours varied from 4-8 hr per day being less during the monsoon season (July=3.5-4h/day) and maximum in the premonsoon $($ May $=7-8 \mathrm{~h} /$ day). Thus, a total of ca. 110 $\mathrm{hr}$ of sampling was carried out during the entire study period. Butterflies were recorded up to $20 \mathrm{~m}$ on both sides of the transect and on the river bed of Huma Khola near Huma Village. In addition, a transect (500m) uphill along the forest stream which flows into the river Sankosh at the U-turn near Kerabari was also sampled by trekking for a day (04 March 2011). During each season sampling was carried out for 3-4 successive days at a stretch on these trails. Butterflies were identified mainly by taking photographs, and using field guides for identification (Evans 1932; Wynter-Blyth 1957; D’Abrera 1982，1985，1986; Smith 1989, 2006; Haribal 1992; Kehimkar 2008). Identification of some species of the Neptis soma group (Nymphalidae) and the Telicota colon group (Hesperiidae) was based on wing pattern as captured in the images, and not based on the genitalia. Hence these might require confirmation.

\section{Data Analysis}

\section{Species Accumulation Curve}

Data for the number of species recoded in each season was pooled. Species accumulation curve was then plotted seasonally from the first to the last sampling to see the rate of species accumulation during each of the five successive samplings.

\section{Relative Abundance}

The abundance data for each butterfly species for all the five seasons combined was pooled separately to get the overall relative abundance status of each species. This data was then sorted in descending order from highest to lowest value and species were then placed in four different classes based upon their respective quartile divisions from very common to uncommon, respectively i.e. VC - very common or Q1 (7-217 number of individuals sampled); C - common or Q2 (4-6); FC - fairly common or Q3 (2-3); UC uncommon or Q4 (1), respectively.

\section{Student's t-test}

Relative abundance data of 'very common' species (Q4; $n=48)$ of butterflies for individual seasons $(n=5)$ was then subjected to 'paired t-tests' (both twotailed and one-tailed) to see if the seasonal variations between two different seasons were significant at $\mathrm{p}<$ 0.05 using SPSS 14 software. [Data was tested for normality prior to analysis and non-parametric tests were followed accordingly to look at the variations].

\section{Simpson's Index}

As species richness and evenness increase, diversity increases. 'Simpson's Diversity Index' takes into account both richness and evenness (Evenness is a measure of the relative abundance of the different species making up the richness of an area). 'Simpson's Index of Diversity' was calculated and used here to see the seasonal variation /trend in species diversity of butterflies in the lowland forests of Bhutan. Simpson's Index (D) (Simpson 1949) measures the probability that two individuals randomly selected from a sample will belong to the same species (or some category other than species).

$$
\mathrm{D}=\sum \mathrm{n}(\mathrm{n}-1) / \mathrm{N}(\mathrm{N}-1)
$$

$\mathrm{n}=$ the total number of organisms of a particular species $\mathrm{N}=$ the total number of organisms of all species

The value of $\mathrm{D}$ ranges between 0 and 1 . With this index, 0 represents infinite diversity and 1 no diversity. That is, the bigger the value of $\mathrm{D}$, the lower the diversity. As this is neither intuitive nor logical, to get over this problem, D was subtracted from 1 to give Simpson's Index of Diversity $=1-D$. The value of 
this index also ranges between 0 and 1 , the greater the value, the greater the sample diversity. In this case, the index represents the probability that two individuals randomly selected from a sample will belong to different species.

\section{Sørensen's Similarity Index}

This index or $\beta$ was calculated to see the species similarity of butterflies between different seasons in lowland forests.

$$
\beta=2 c /(S 1+S 2)
$$

Here, $\mathrm{S} 1=$ the total number of species recorded in one season, $\mathrm{S} 2=$ the total number of species recorded in a different season, and $\mathrm{c}=$ the number of species common to both the seasons.

The Sørensen's similarity index (Sørensen 1948) is a very simple measure of beta diversity, ranging from a value of 0 where there is no species overlap between the communities, to a value of 1 when exactly the same species are found in both communities.

\section{RESULTS AND DISCUSSION}

A total of 213 species of butterflies were recorded during the five sampling surveys carried out in 18 days in the study area. A complete checklist of butterflies sampled in the study area is given in the Table 1). Amongst these, only 87 species are common with van der Poel \& Wangchuk (2007) list for areas between $800-3,000 \mathrm{~m}$ in Bhutan.

\section{Species accumulation curve}

The increasing trend in the species accumulation curve shows that new species were added during every season up to the last sampling at about the same rate (Fig. 1). This suggests that there is a potential of adding more species to the current list of the area and there is a need to undertake more surveys for a preparing an exhaustive list.

How many species could be there in the study area?

A total of 22 species of the family Papilionidae were recorded in this which suggests that the species richness of the area could be as high as 297 species based on family proportion model (Singh \& Pandey 2004) by taking Paplionidae species proportion as

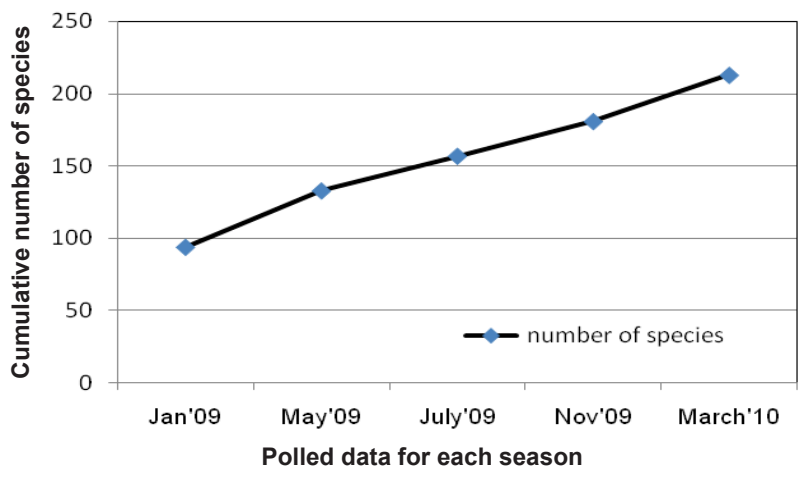

Figure 1. Species accumulation curve in sampling butterflies through different seasons in tropical lowland forests of Bhutan (January 2009-March 2010).

$7.4 \%$ of the total for northeastern India (Wynter-Blyth 1957). The present findings thus represent only $70.6 \%$ of the species found in the study area. The family Pieridae represents only $10.8 \%$ of the total; Lycaenidae 24.0\%; Nymphalidae $42.4 \%$ and Hesperidae $13.3 \%$, respectively, of the total species sampled. As per Singh \& Pandey (2004) model, families Lycaenidae and Hesperiidae should represent $29.5 \%$ and $21.9 \%$, respectively, of the total number of species sampled in northeastern India. These two families are thus under represented in the present sampling and there is a need to look for more species.

\section{Seasonality of butterflies in subtropical lowland forests}

Species richness and diversity: The seasonal variation in Simpson's Index of Diversity (Fig. 2) and the number of species sampled during each season (pooled data; Fig. 3), suggests that species diversity and richness both peak during March (spring) and are lowest in January (winter). A second peak was observed during November which was smaller than the first peak. This seasonal pattern of diversity in butterflies is very typical of the lower foothills and valleys of the Himalaya, i.e. Dehradun Valley (400700 m) (Singh \& Bhandari 2003) or even Calcutta (Wynter-Blyth 1957). However, the timing of the two seasonal peaks, as observed in this study, is slightly different in pattern as compared to the butterflies found in the higher reaches of the Himalaya where the first peak is slightly late in April-May while the second peak is slightly earlier in September-October i.e. Bhutan between 1,200-3,000 m (van der Poel \& Wangchuk 2007) or Shimla at around 2000m (Wynter- 

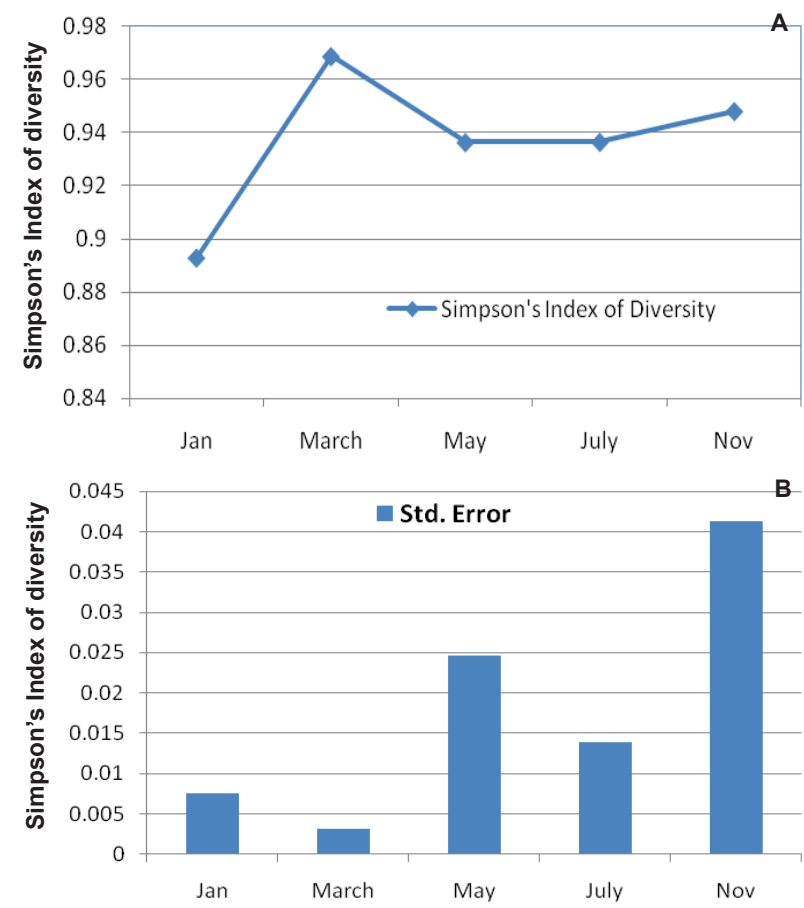

Figure 2. Seasonal variation in (A) species diversity of butterflies, and (B) its standard error in subtropical lowland forests of Bhutan (January 2009-March 2010).

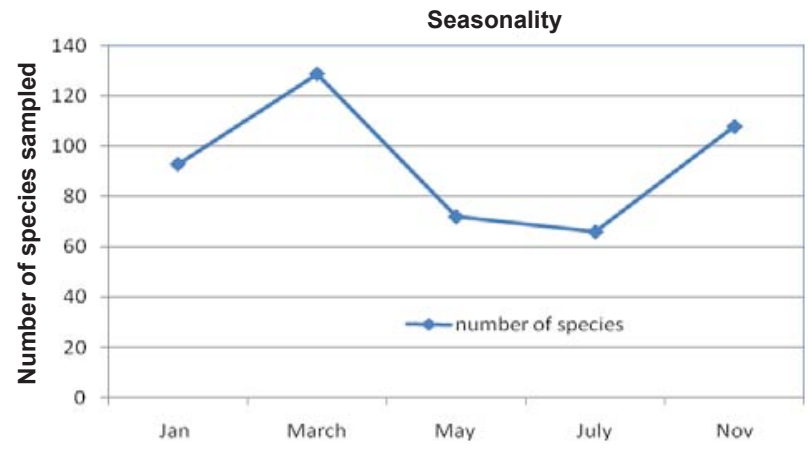

Figure 3. Seasonal variation in number of butterfly species (pooled) in subtropical lowland forests of Bhutan (January 2009-March 2010).

Blyth 1957). This is because spring arrives late in the higher reaches so butterflies emerge later and as winter sets in early in the hills, so butterflies go into hibernation early as compared to the low land forests.

Species similarity between seasons: Sørensen's similarity index between seasons varied between 0.3076 to 0.5656 . This suggests that the species composition also changed with the seasons in these forests. Greatest species similarity was observed during January and November followed by March and November, respectively (Fig. 4). However, the least

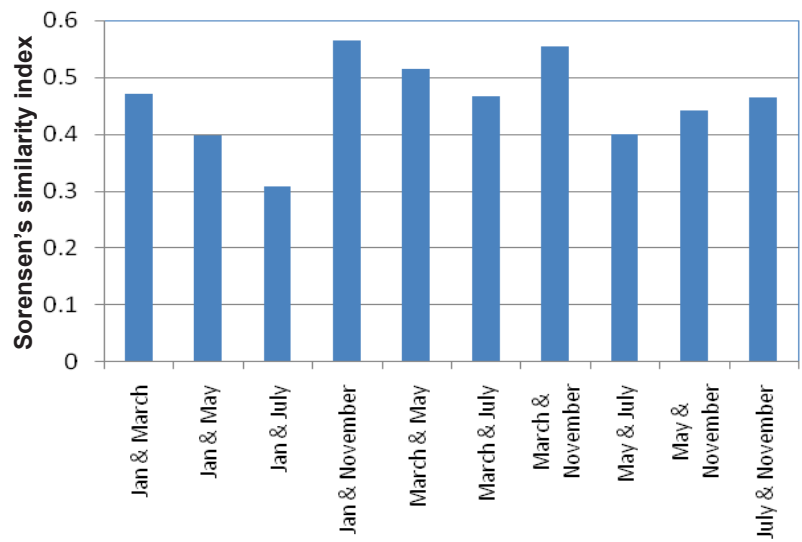

Figure 4. Butterfly species similarity between different seasons in sub-tropical lowland forests of Bhutan (January 2009-March 2010).

species similarity in species composition was observed between January and July followed by January and May, respectively (Fig. 4).

Relative abundance: The five most abundant species in the study area were Euploea mulciber mulciber, Ixais pyrene pirenassa, Appias lyncida hippoides, Tirumala septentrionis and Eurema blanda silhetana. The seasonal variations in relative abundance of butterflies for 'very common' species ( $\mathrm{n}=48 ; \mathrm{Q} 4)$ were found to be significant ( $\mathrm{p}<0.05$; Student's t-test) between only January-March; March-May and March-November. Thus, the abundance of common butterflies during 'spring' varied significantly as compared to 'winter', 'dry summer/pre-monsoon' and 'post-monsoon' seasons.

Species of conservation priority: At least 11 species (Pareronia avatar avatar, Nacaduba pactolus continentalis, Porostas aluta coelestis, Lampides boeticus, Melanitis zitenius zitenius, Elymnias vasudeva vasudeva, Mycalesis mestra retus, Charaxes marmax, Athyma ranga ranga, Neptis manasa manasa and Neptis soma) recorded in the study area have been listed in Schedules I and II of the Indian Wildlife (Protection) Act, 1972 (IWPA), but none in the 'Forest Nature and Conservation Act of Bhutan 1995' or IUCN Red list of Threatened species (IUCN 2010). Amongst these 11 species, except for Lampides boeticus, all other taxa are 'rare' throughout their distribution range (Evans 1932; Wynter-Blyth 1957) and are thus species of conservation priority over rest of the other taxa in the study area. Besides, one more species, Burala amara Moore, which has been omitted from the IWPA, is also 
Table 1. Checklist of butterflies recorded in subtropical lowland forests of Bhutan along the Sankosh River (118-220 m; January 2009-March 2010).

\begin{tabular}{|c|c|c|c|c|c|c|c|c|}
\hline & Family/Scientific name & Common Name & Jan & Mar & May & Jul & Nov & $\begin{array}{c}\text { Relative } \\
\text { Abundance }\end{array}$ \\
\hline A. & \multicolumn{8}{|l|}{ Papiliondae } \\
\hline 1 & Graphium sarpedon sarpedon Linnaeus & Common Blue Bottle (Image 9) & & * & * & * & * & 14 \\
\hline 2 & Graphium doson axion Felder & Common Jay (Image 10) & * & & & & & 3 \\
\hline 3 & Graphium chironides Honrath & Veined Jay & & & * & & & 9 \\
\hline 4 & Graphium agamemnon agamemnon Linnaeus & Tailed Jay & & * & & * & * & 3 \\
\hline 5 & Graphium nomius Swinhoe & Spot Swordtail (Image 11) & & * & & & & 14 \\
\hline 6 & Graphium agetes agetes Westwood & Four-bar Swordtail (Image 12) & & * & * & & & 3 \\
\hline 7 & Graphium macareus indicus Rothschild & Lesser Zebra (Image 13) & & * & & * & * & 5 \\
\hline 8 & Graphium xenocles phrontis DeNiceville & Great Zebra & & * & & & & 3 \\
\hline 9 & Graphium antiphates pompilius Fabricius & Fivebar Swordtail (Image 14) & & * & & & * & 7 \\
\hline 10 & Papilio clytia clytia Linnaeus & Common Mime & & * & * & & & 3 \\
\hline 11 & Papilio polytes stichioides Evans & Common Mormon & * & * & * & * & * & 46 \\
\hline 12 & Papilio castor castor Westwood & Common Raven & & * & & & & 2 \\
\hline 13 & Papilio helenus helenus Linnaeus & Red Helen (Image 15) & & * & * & * & * & 18 \\
\hline 14 & Papilio nephelus chaon Westwood & Yellow Helen (Image 16) & & * & * & * & * & 17 \\
\hline 15 & Papilio memnon agenor Linnaeus & Great Mormon (Image 17) & & * & & * & & 3 \\
\hline 16 & Papilio protenor euprotenor Fruhstorfer & Spangle & & & & * & * & 2 \\
\hline 17 & Papilio alcmeno Felder & Redbreast & & * & & * & * & 4 \\
\hline 18 & Papilio demoleus demoleus Linnaeus & Lime Butterfly & & & * & & & 1 \\
\hline 19 & Papilio bianor polyctor Boisduval & Common Peacock & & * & * & * & & 3 \\
\hline 20 & Atrophaneura varuna astorion Westwood & Common Batwing & & * & & * & * & 3 \\
\hline 21 & Pachliopta aristolochiae aristolochiae Fabricius & Common Rose & & * & & & & 1 \\
\hline 22 & Troides aeacus Felder & Golden Birdwing & * & * & & * & & 4 \\
\hline B. & \multicolumn{8}{|l|}{ Pieridae } \\
\hline 23 & Eurema blanda silhetana Wallace & Three Spot Grass Yellow & * & * & * & * & * & 53 \\
\hline 24 & Eurema hecabe hecabe Linnaeus & Common Grass Yellow & & * & * & * & * & 17 \\
\hline 25 & Gandaca harina assamica Moore & Tree Yellow & * & * & * & & * & 23 \\
\hline 26 & Catopsilia pomona Linnaeus. & Common Emigrant & * & * & & * & & 23 \\
\hline 27 & Catopsilia pyranthe minna Herbst & Mottled Emigrant & & * & & * & * & 32 \\
\hline 28 & Ixias Marianne Cramer & White Orange Tip & & & & & * & 2 \\
\hline 29 & Ixais pyrene pirenassa Wallace & Yellow Orange Tip (Image 18) & * & * & * & & * & 123 \\
\hline 30 & Hebomoia glaucippe glaucippe Linnaeus & Great Orange Tip (Image 19) & * & * & * & * & * & 32 \\
\hline 31 & Pareronia valeria hippa Fabricius & Common Wanderer & * & & & & & 1 \\
\hline 32 & Pareronia avatar avatar Moore [IWPA Sch. II] & Pale Wanderer & & & * & & & 1 \\
\hline 33 & Appias lyncida hippoides Moore & Chocolate Albatross (Image 20) & * & * & * & & * & 99 \\
\hline 34 & Appias albino darada Felder & Common Albatross & * & & & & * & 11 \\
\hline 35 & Appias lalage lalage Doubleday & Spot Puffin & * & * & & & & 7 \\
\hline 36 & Pieris canidia indica Evans & Indian Cabbage White & * & & & & & 1 \\
\hline 37 & Cepora nerissa phryne Fabricius & Common Gull & & * & * & * & * & 39 \\
\hline 38 & Cepora nadina nadina Lucas & Lesser Gull & & * & * & * & * & 23 \\
\hline 39 & Prioneris thestylis Doubleday & Spotted Sawtooth (Image 21) & * & * & & & * & 6 \\
\hline 40 & Delias pasithoe Linnaeus & Red Base Jezebel (Image 22) & * & * & & & * & 4 \\
\hline 41 & Delias descombesi leucaeantha Fruhstorfer & Red Spot Jezebel (Image 23) & * & & & * & * & 7 \\
\hline 42 & Delias thysbe pyramus Wallace & Red-breasted Jezebel (Image 24) & * & * & & & & 5 \\
\hline
\end{tabular}




\begin{tabular}{|c|c|c|c|c|c|c|c|c|}
\hline & Family/Scientific name & Common Name & Jan & Mar & May & Jul & Nov & $\begin{array}{c}\text { Relative } \\
\text { Abundance }\end{array}$ \\
\hline 43 & Delias agostina Hewitson & Yellow Jezebel & * & & & & & 1 \\
\hline 44 & Delias hyparete hierte Drury & Painted Jezebel (Image 25) & & & * & & & 1 \\
\hline 45 & Leptosia nina nina Fabricius & Psyche & * & * & & & & 2 \\
\hline c. & \multicolumn{8}{|l|}{ Lycaenidae } \\
\hline 46 & Poritia hewitsoni hewitsoni Moore & Common Gem & & & & & * & 2 \\
\hline 47 & Spalgis epius epius Westwood & Apefly (Image 26) & * & & & & & 1 \\
\hline 48 & Curetis bulis Doubleday \& Hewitson & Bright Sunbeam & & * & * & & & 4 \\
\hline 49 & Curetis dentata dentata Moore & Angled Sunbeam (Image 27) & & * & & & & 2 \\
\hline 50 & Chrysozephyrus assamica Tytler* & Silver Hairstreak & & & * & & & 1 \\
\hline 51 & Arhopala pseudocentaurus Doubleday & Western Centaur Oakblue & * & * & & & * & 3 \\
\hline 52 & Arhopala abseus Hewitson & Aberrant Oak Blue & & * & * & & * & 3 \\
\hline 53 & Arhopala atrax Hewitson & Indian Oak Blue & & & * & & & 1 \\
\hline 54 & Surendra quercetorum quercetorum Moore & Common Acacia Blue & & * & * & & & 2 \\
\hline 55 & Loxura atymnus continentalis Fruhstorfer & Yamfly & & & * & * & & 4 \\
\hline 56 & Cheritra freja freja Fabricius & Common Imperial (Image 28) & * & * & * & & * & 9 \\
\hline 57 & Remelana jangala ravata Moore & Chocolate Royal (Image 29) & * & & & & & 3 \\
\hline 58 & Tajuria cippus cippus Fabricius & Peacock Royal & * & & & & & 1 \\
\hline 59 & Pratapa deva lila Moore & Tufted White Royal & & & & & * & 1 \\
\hline 60 & Hypolycaena erylus himarantus Moore & Common Tit & * & & & & * & 12 \\
\hline 61 & Zeltus amasa Hewitson & Fluffy Tit (Image 30) & & & * & & & 1 \\
\hline 62 & Deudorix epijarbas Moore & Cornelian & & * & & & & 1 \\
\hline 63 & Rapala varuna orseis Hewitson & Indigo Flash & & & & & * & 1 \\
\hline 64 & Rapala pheretima petosiris Hewitson & Copper Flash & * & & & & * & 28 \\
\hline 65 & Rapala jarbus Fabricius & Indian Red Flash & & * & & & * & 2 \\
\hline 66 & Catapaecilma elegans major Fruhstorfer & Common Tensil & & * & & & & 2 \\
\hline 67 & Spindasis vulcanus vulcanus Fabricius & Common Silverline & & * & & & & 1 \\
\hline 68 & Spindasis lohita himalayanus Moore & Long-banded Silverline & & * & & & * & 8 \\
\hline 69 & Heliophorus epicles indicus Fruhstorfer & Purple Sapphire & * & * & * & & * & 5 \\
\hline 70 & Anthene emolus emolus Godart & Common Ciliate Blue & * & * & * & & & 3 \\
\hline 71 & Anthene lycaenina lycambes Hewitson & Pointed Ciliate Blue & & * & & * & & 2 \\
\hline 72 & Castalius rosimon rosimon Fabricius & Common Pierrot & * & & * & & & 2 \\
\hline 73 & Leptotes plinius Fabricius & Zebra Blue & & & * & & & 1 \\
\hline 74 & $\begin{array}{l}\text { Nacaduba pactolus continentalis Fruhstorfer } \\
\text { [IWPA Sch. II] }\end{array}$ & Large 4-Lineblue & * & & & & & 1 \\
\hline 75 & Nacaduba kurava euplea & Transparent 6- Lineblue & & & * & & & 2 \\
\hline 76 & Nacaduba beroe Felder & Opaque 6 - Lineblue & & & * & & & 3 \\
\hline 77 & $\begin{array}{l}\text { Porostas aluta coelestis de Niceville } \\
\text { [IWPA Sch. II] }\end{array}$ & Banded Lineblue & * & & & & * & 2 \\
\hline 78 & Prosotas dubiosa indica Evans & Tailless Line Blue & & & & * & & 1 \\
\hline 79 & Jamides bochus Cramer & Dark Cerulean & * & * & * & & & 6 \\
\hline 80 & Jamides celeno celeno Cramer & Common Cerulean & * & * & * & & * & 49 \\
\hline 81 & Jamides alecto eurysaces Fruhstorfer & Metallic Cerulean & & * & & & & 1 \\
\hline 82 & Catochrysops panormus Felder & Silver Forget-me-not & & * & * & & & 2 \\
\hline 83 & Catochrysops Strabo Fabricius & Forget- me- not & & * & & & & 1 \\
\hline 84 & Pseudozizeeria maha maha Kollar & Pale Grass Blue & & * & & * & & 2 \\
\hline 85 & Lampides boeticus Linnaeus [IWPA Sch. II] & Pea Blue & & * & & & & 1 \\
\hline
\end{tabular}




\begin{tabular}{|c|c|c|c|c|c|c|c|c|}
\hline & Family/Scientific name & Common Name & Jan & Mar & May & Jul & Nov & $\begin{array}{c}\text { Relative } \\
\text { Abundance }\end{array}$ \\
\hline 86 & Zizeeria karsandra Moore & Dark Grass Blue & & & * & * & & 2 \\
\hline 87 & Everes lacturnus assamica Tytler & Indian Cupid & & & & & * & 1 \\
\hline 88 & Neopithecops zalmora Butler & Quaker & * & * & * & & & 4 \\
\hline 89 & Megisba malaya sikkima Moore & Malayan & & * & & * & & 3 \\
\hline 90 & Acytolepis puspa gisca Fruhstorfer & Common Hedge Blue & & * & & & & 1 \\
\hline 91 & Celastrina lavendularis placida de Niceville & Plain Hedge Blue & & & & * & & 1 \\
\hline 92 & Chilades lajus lajus Evans & Lime Blue & & * & * & * & & 6 \\
\hline 93 & Abisara fylla Doubleday & Dark Judy & * & * & & & * & 3 \\
\hline 94 & Abisara echerius suffuse Moore & Plum Judy & & & & * & & 1 \\
\hline 95 & Abisara neophron neophron Hewitson & Tailed Judy & & * & & & & 2 \\
\hline 96 & Zemeros flegyas indicus Fruhstorfer & Punchinello & * & * & * & * & * & 10 \\
\hline D. & Nymphalidae & & & & & & & \\
\hline 97 & Libythea lepita lepita Moore & Common Beak & & * & & & & 1 \\
\hline 98 & Tirumala limniace mertina Fruhstorfer & Blue Tiger & * & * & * & * & * & 15 \\
\hline 99 & Tirumala septentrionis Butler & Dark Blue Tiger & * & & * & * & & 66 \\
\hline 100 & Danaus genutia Cramer & Striped Tiger & * & * & * & * & * & 11 \\
\hline 101 & Danaus chrysippus Linnaeus & Plain Tiger & * & * & & * & * & 12 \\
\hline 102 & Parantica aglea melanoides Moore & Glassy Tiger & * & * & & * & * & 12 \\
\hline 103 & Parantica sita tylia Gray & Chestnut Tiger & * & & & & * & 2 \\
\hline 104 & Parantica melaneus plantenston Fruhstorfer & Chocolate Tiger (Image 31) & * & & & * & & 5 \\
\hline 105 & $\begin{array}{l}\text { Euploea mulciber mulciber Cramer } \\
\text { [IWPA Sch. IV] }\end{array}$ & Striped-blue Crow & * & * & * & * & * & 217 \\
\hline 106 & Euploea radamanthus Fabricius & Magpie Crow (Image 32) & & & & * & * & 4 \\
\hline 107 & Euploea midamus splendens Butler & Blue Spotted Crow & * & & & & & 13 \\
\hline 108 & Euploea algae deione Westwood & Long-branded Crow (Image 33) & * & & & * & & 16 \\
\hline 109 & Euploea core core Cramer & Common Crow & * & * & * & * & * & 13 \\
\hline 110 & Polyura athamas athamas Drury & Common Nawab & * & * & * & * & * & 9 \\
\hline 111 & Polyura eudamippus Doubleday & Great Nawab (Image 34) & & * & & & & 2 \\
\hline 112 & Polyura arja Felder & Pallid Nawab (Image 35) & & & & & * & 2 \\
\hline 113 & Charaxes bernardus Fabricius & Tawny Rajah & & * & * & * & * & 9 \\
\hline 114 & Charaxes marmax Westwood [IWPA Sch. II] & Yellow Rajah & & * & & * & * & 3 \\
\hline 115 & Charaxes solon fabius Fabricius & Black Rajah & & & & * & * & 2 \\
\hline 116 & Faunis canens Hubner & Common Faun & & & & * & & 1 \\
\hline 117 & Discophora sondaica zal Westwood & Common Duffer & & & & & * & 2 \\
\hline 118 & Melanitis leda ismene Cramer & Common Evening Brown & * & * & * & & * & 5 \\
\hline 119 & Melanitis phedima bela Moore & Dark Evening Brown & * & * & & & * & 3 \\
\hline 120 & Melanitis zitenius zitenius Herbst [IWPA Sch. II] & Great Evening Brown & * & * & & & * & 5 \\
\hline 121 & Lethe europa niladana Fruhstorfer & Bamboo Treebrown & & & & * & & 1 \\
\hline 122 & Lethe rohria rohira Fabricius & Common Treebrown & * & & & * & & 3 \\
\hline 123 & Lethe confuse confuse Aurivillius & Banded Treebrown & & * & & & * & 3 \\
\hline 124 & Lethe mekara mekara Moore & Common Red Forester (Image 36) & * & * & & & & 2 \\
\hline 125 & Lethe verma sintica Fruhstorfer & Straight-banded Treebrown & & & * & & & 2 \\
\hline 126 & Elymnias hypermnestra undularis Drury & Common Palmfly & * & * & * & * & * & 11 \\
\hline 127 & $\begin{array}{l}\text { Elymnias vasudeva vasudeva Moore } \\
\text { [IWPA Sch. II] }\end{array}$ & Jezebel Palmfly (Image 37) & & & & & * & 1 \\
\hline 128 & Mycalesis anaxias aemate Fruhstorfer & White Bar Bushbrown & & * & & & & 1 \\
\hline
\end{tabular}




\begin{tabular}{|c|c|c|c|c|c|c|c|c|}
\hline & Family/Scientific name & Common Name & Jan & Mar & May & Jul & Nov & $\begin{array}{l}\text { Relative } \\
\text { Abundance }\end{array}$ \\
\hline 129 & $\begin{array}{l}\text { Mycalesis mestra retus Fruhstorfer } \\
\text { [IWPA Sch. II] }\end{array}$ & White-edged Bushbrown & * & & & & & 1 \\
\hline 130 & Mycalesis perseus blasieus Fabricius & Common Bushbrown & * & * & * & * & * & 33 \\
\hline 131 & Mycalesis malsara Moore & White line Bushbrown & & * & & & & 3 \\
\hline 132 & Mycalesis lepcha lepcha Moore & Lepcha Bushbrown & & & & & * & 1 \\
\hline 133 & Orsotrioena medus meudus Fabricius & Medus Brown/Jungle Brown & & * & * & & & 8 \\
\hline 134 & Ypthima baldus baldus Fabricius & Common Five Ring & * & * & * & * & * & 47 \\
\hline 135 & Cethosia biblis tisamena Fruhstorfer & Red Lacewing & & & & * & * & 4 \\
\hline 136 & Vindula erota erota Fabricius & Cruiser (Image 38) & & & & * & * & 4 \\
\hline 137 & Cirrochroa aoris aoris Doubleday & Large Yeoman & * & * & * & * & * & 15 \\
\hline 138 & Cirrochroa tyche mithila Moore & Common Yeoman & * & * & * & * & * & 11 \\
\hline 139 & Vagrans egista sinha Kollar & Vagrant & * & & & & * & 2 \\
\hline 140 & Phalanta phalantha Drury & Common Leopard & & * & * & & * & 23 \\
\hline 141 & Moduza procris procris Cramer & Commander (Image 39) & * & * & & & & 3 \\
\hline 142 & Athyma perius Linnaeus & Common Sergeant & * & & & & & 1 \\
\hline 143 & Athyma asura asura Moore & Studded Sergeant & & * & & & & 1 \\
\hline 144 & Athyma ranga ranga Moore [IWPA Sch. II] & Black Vein Sergeant (Image 40) & * & * & * & & * & 7 \\
\hline 145 & Athyma selenophora selenophora Kollar & Staff Sergeant & * & & & & * & 2 \\
\hline 146 & Athyma cama Moore & Orange Staff Sergeant & & * & & & & 1 \\
\hline 147 & Athyma nefte inara Doubleday & Colour Sergeant (Image 41) & * & & & * & & 2 \\
\hline 148 & Pantoporia hordonia hordonia Stoll & Common Lascar & * & * & * & & * & 9 \\
\hline 149 & Neptis miah miah Moore & Small Yellow Sailer & * & & & & & 1 \\
\hline 150 & Neptis hylas varmona Moore & Common Sailer & * & * & * & & * & 26 \\
\hline 151 & Neptis soma soma Moore [IWPA Sch. II] & Sullied Sailer & & * & * & * & & 5 \\
\hline 152 & Neptis pseudovikasi Moore & Dingy Sailor (Image 42) & & & & & * & 1 \\
\hline 153 & Neptis ananta ochracea Evans & Yellow Sailer (Image 43) & & * & & * & * & 4 \\
\hline 154 & Neptis manasa Moore [IWPA Sch. I] & Pale Hockey Stick Sailer (Image 44) & & & & & * & 1 \\
\hline 155 & Neptis cartica cartica Moore & Plain Sailer & & * & & & & 1 \\
\hline 156 & Phaedyma columella ophiana Moore & Short-banded Sailer & & * & & & & 1 \\
\hline 157 & Lebadea martha martha Fabricius & Knight (Image 45) & * & * & & & * & 6 \\
\hline 158 & Euthalia monina kesava Moore & Powdered Baron & & & & & * & 2 \\
\hline 159 & Euthalia phemius Doubleday & White-edged Blue Baron & * & & & & * & 4 \\
\hline 160 & Euthalia aconthea suddhodana Fruhstorfer & Common Baron & & * & & & * & 5 \\
\hline 161 & $\begin{array}{l}\text { Euthalia Iubentina indica Fruhstorfer } \\
\text { [IWPA Sch. IV] }\end{array}$ & Gaudy Baron & & & & * & * & 2 \\
\hline 162 & Tanaecia lepidea lepidea Butler & Grey Count (Image 46) & * & * & & & * & 3 \\
\hline 163 & Tanaecia julii appiades Menetries & Common Earl & & * & & & * & 4 \\
\hline 164 & Lexias dirtea khasiana Swinhoe & Dark Archduke (Images 47a,b) & & * & * & & * & 4 \\
\hline 165 & Cyrestis thyodamas thyodamas Boisduval & Common Map & * & * & * & & * & 5 \\
\hline 166 & Chersonesia risa Doubleday & Common Maplet (Image 48) & & & & & * & 2 \\
\hline 167 & Stibochiona nicea nicea Gray & Popinjay & & * & & & * & 2 \\
\hline 168 & Ariadne ariadne pallidor Fruhstorfer & Angled Castor & * & & & & & 1 \\
\hline 169 & Ariadne merione assama Evans & Common Castor & & * & & & & 1 \\
\hline 170 & Apatura ambica ambica Kollar & Indian Purple Emperor & & * & & & & 1 \\
\hline 171 & Rohana parisatis parosatis Westwood & Black Prince (Image 49) & & * & * & & * & 11 \\
\hline 172 & Hestina nama Doubleday & Circe & * & & & & * & 2 \\
\hline
\end{tabular}




\begin{tabular}{|c|c|c|c|c|c|c|c|c|}
\hline & Family/Scientific name & Common Name & Jan & Mar & May & Jul & Nov & $\begin{array}{l}\text { Relative } \\
\text { Abundance }\end{array}$ \\
\hline 173 & Symbrenthia lilaea khasiana Moore & Common Jester & * & * & & & * & 8 \\
\hline 174 & Symbrenthia hypselis cotanda Moore & Himalayan Jester & * & & & & * & 2 \\
\hline 175 & Vanessa indica indica Herbst & Indian Red Admiral & * & & & & * & 2 \\
\hline 176 & Kaniska canace canace Linnaeus & Blue Admiral & & & & & * & 1 \\
\hline 177 & Vanessa cardui Linnaeus & Painted Lady & * & & & & & 1 \\
\hline 178 & Junonia orithya ocyale Hubner & Blue Pansy & * & & & & * & 2 \\
\hline 179 & Junonia hierta magna Evans & Yellow Pansy & * & & & & & 1 \\
\hline 180 & Junonia iphita iphita Cramer & Chocolate Pansy & * & * & & & & 2 \\
\hline 181 & Junonia atlites Linnaeus & Grey Pansy & * & & & * & * & 3 \\
\hline 182 & Junonia almana almana Linnaeus & Peacock Pansy & * & & & & * & 2 \\
\hline 183 & Junonia lemonias lemonias Linnaeus & Lemon Pansy & * & * & * & * & * & 21 \\
\hline 184 & Hypolimnas bolina Linnaeus & Great Eggfly & * & * & * & * & * & 5 \\
\hline 185 & Kallima inachus inachus Boisduval & Orange Oakleaf & * & * & & * & & 3 \\
\hline 186 & Doleschallia bisaltide indica Moore & Autumn Leaf & & * & * & & & 2 \\
\hline E. & Hesperiidae & & & & & & & \\
\hline 187 & Burala oedipodea aegina Plotz & Branded Orange Awlet & * & & & & * & 2 \\
\hline 188 & Burala amara Moore & Small Green Awlet (Image 50) & & * & & & & 1 \\
\hline 189 & Burala jaina jaina Moore & Orange Awlet (Image 51) & & * & * & & & 2 \\
\hline 190 & Hasora badra badra Moore & Common Awl & & & * & & & 2 \\
\hline 191 & Hasora vitta indica Evans [IWPA Sch. IV] & Plain Banded Awl & & & * & & & 2 \\
\hline 192 & Sarangesa dasahara dasahara Moore & Common Small Flat & * & * & & & & 2 \\
\hline 193 & Tagiades japetus khasiana Moore & Common Snow Flat & * & * & & * & & 3 \\
\hline 194 & Pseudocoladenia dan faith Kollar & Fulvous Pied Flat & * & & * & & * & 3 \\
\hline 195 & Gerosis bhagava bhagava Moore & Common Yellow-breasted Flat & & * & & & * & 2 \\
\hline 196 & Seseria dohertyi dohertyi Watson & Himalayan White Flat (Image 52) & & * & & & & 1 \\
\hline 197 & Tagiades gana athos Plotz & Suffused Snow Flat & & & & & * & 5 \\
\hline 198 & Tagiades parra gala Evans & Large Snow Flat (Image 53) & & & & & * & 1 \\
\hline 199 & Odotoptilum angulata Felder & Chestnut Angle & & * & & & & 1 \\
\hline 200 & Oriens goloides gola Moore & Common Dartlet & * & * & & * & & 4 \\
\hline 201 & Telicota colon Fabricius & Pale Palm Dart & & * & & * & * & 3 \\
\hline 202 & Parnara guttatus guttatus Berm & Straight Swift & & * & & * & * & 3 \\
\hline 203 & $\begin{array}{l}\text { Pelopidas assamensis Wood Mason \& de } \\
\text { Niceville [IWPA Sch. IV] }\end{array}$ & Great Swift & * & & & & & 1 \\
\hline 204 & Pithauria straminiepennis Wood Mason & Light Straw Ace (Image 54) & & * & & & & 2 \\
\hline 205 & Arnetta atkinsoni Moore & Atkinson's Bob (Image 55) & & * & * & & & 4 \\
\hline 206 & lambrix salsala salsala Moore & Chestnut Bob & & * & & & * & 3 \\
\hline 207 & Koruthaialos butleri butleri Wood Mason & Dark Velvet Bob & & * & & & & 1 \\
\hline 208 & Matapa aria Moore & Common Redeye & * & & & & & 1 \\
\hline 209 & Matapa sasiarna Moore & Black-veined Redeye (Image 56) & & & & & * & 1 \\
\hline 210 & Udaspes folus Cramer & Grass Demon & & * & & & & 1 \\
\hline 211 & Notocrypta curvifascia Felder & Restricted Demon (Image 57) & * & * & & & * & 3 \\
\hline 212 & Ancistroides nigrita Latreille & Chocolate Demon (Image 58) & & * & & & & 1 \\
\hline 213 & Ochus subvittatus Moore & Tiger Hopper & & & * & & & 2 \\
\hline
\end{tabular}

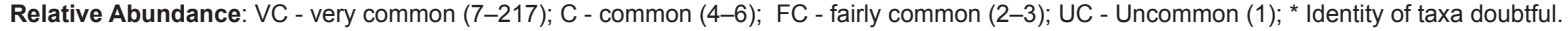




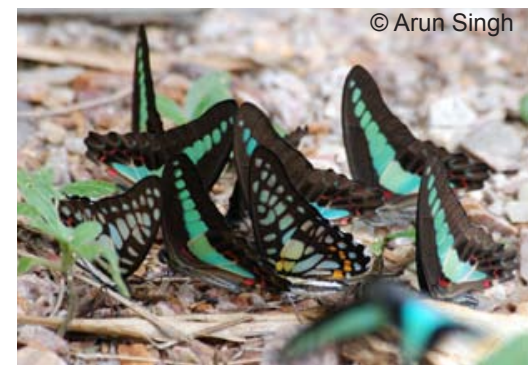

Images 9 \& 10. Common Blue Bottle,

Graphium sarpedon and Common Jay, Graphium doson

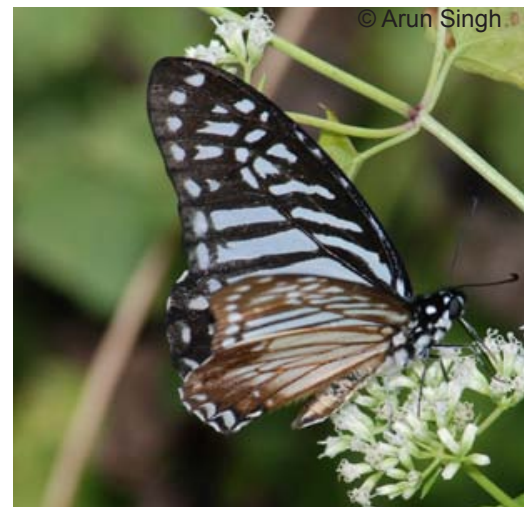

Image 13. Lesser Zebra

Graphium macareu

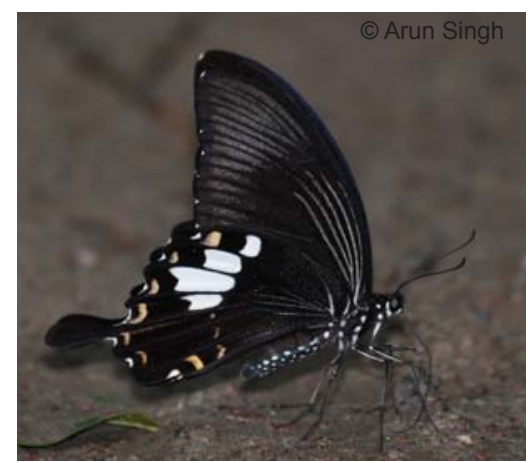

Image 16. Yellow Helen Papilio nephelus

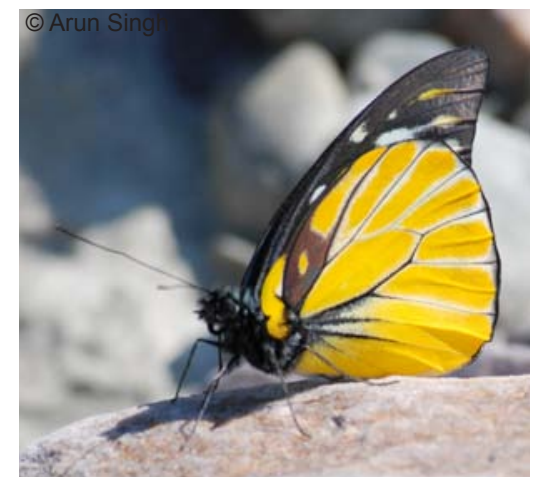

Image 21. Spotted Sawtooth Prioneris thestylis

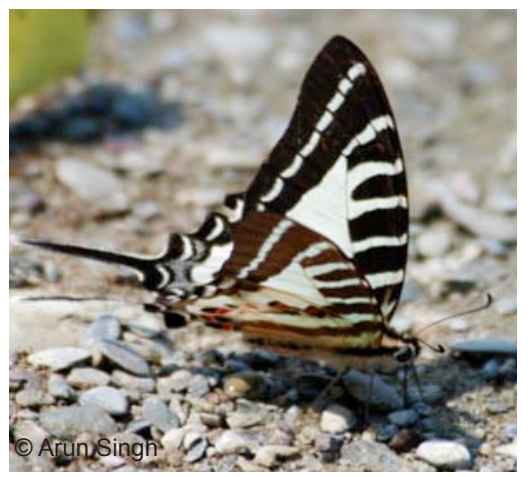

Image 11. Spot Swordtail

Graphium nomius

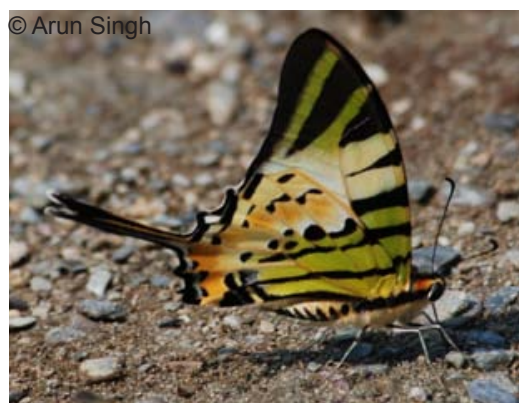

Image 14. Five bar Swordtail

Graphium antiphates pompilius

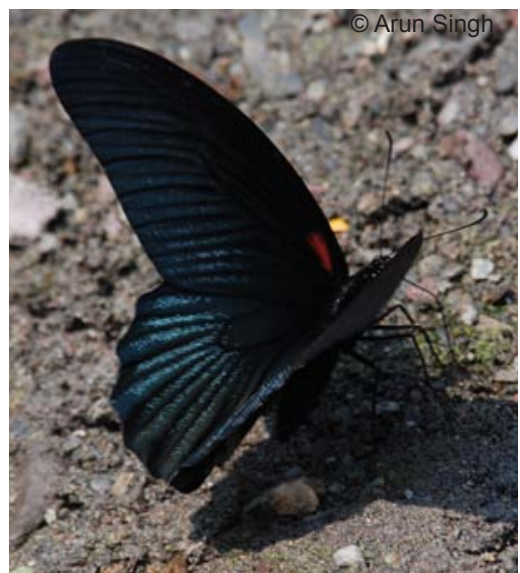

Image 17. Great Mormon

Papilio memnon

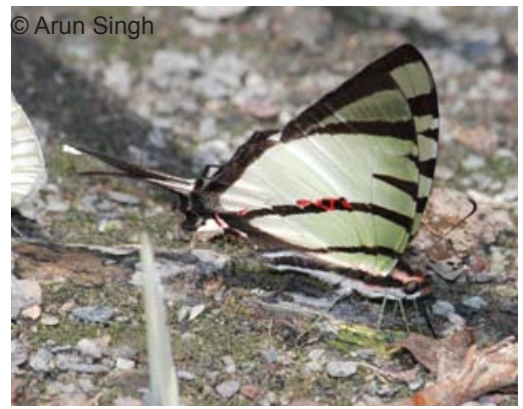

Image 12. Fourbar Swordtail

Graphium agetes agetes

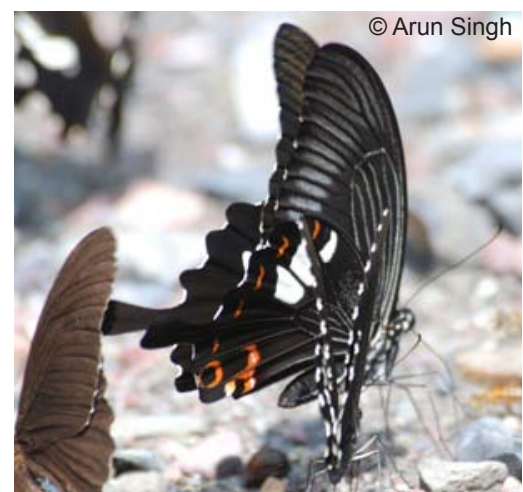

Image 15. Red Helen Papilio helenus

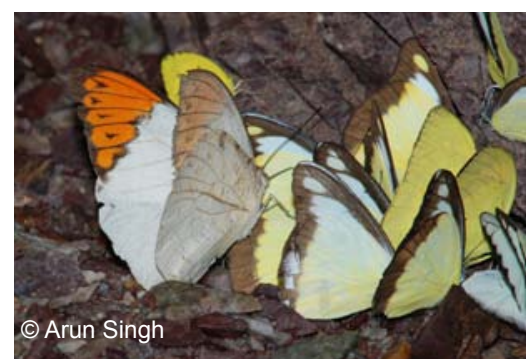

Image 18-20. Great Orange Tip,

Hebomoia glaucippe, Yellow Orange

Tip, Ixais pyrene and Chocolate

Albatross, Appias lyncida

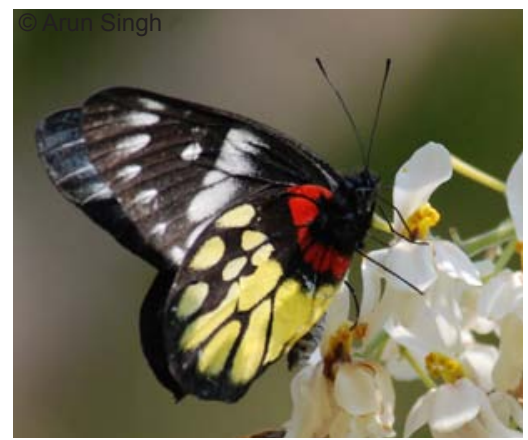

Image 22. Red-Base Jezebel

Delias pasithoe 


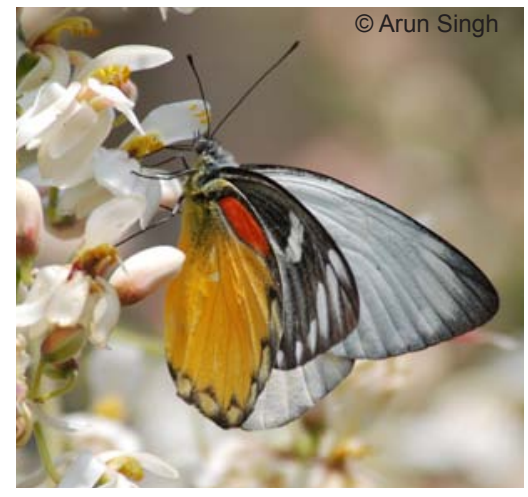

Image 23. Red Spot Jezebel Delias descombesi

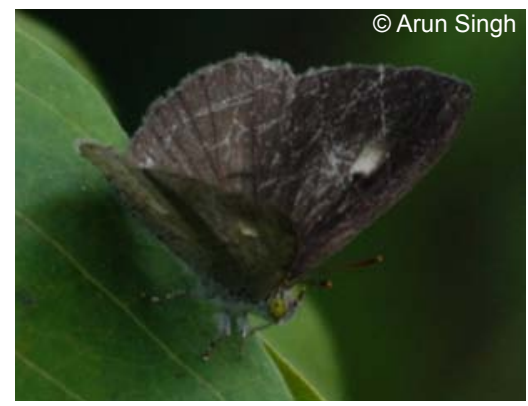

Image 26. Apefly Spalgis epius

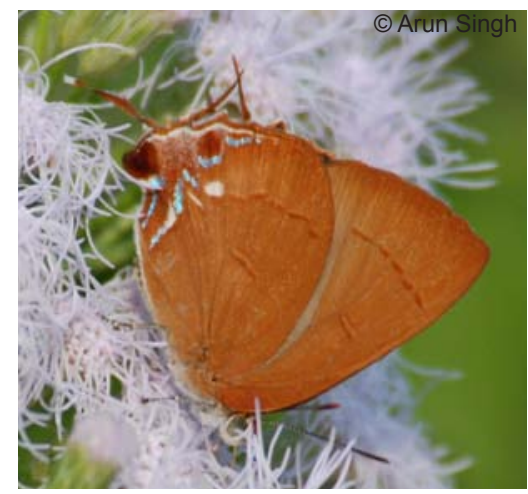

Image 29. Chocolate Royal Eliotia jangala

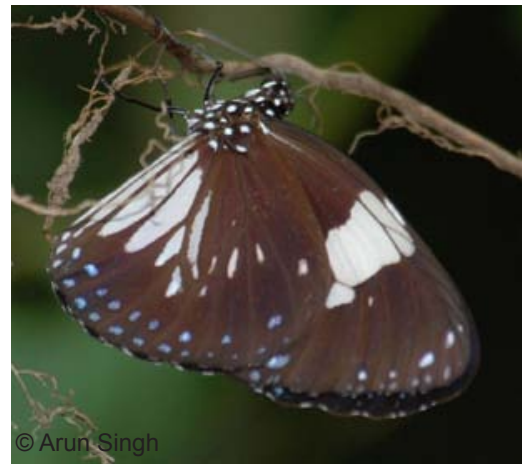

Image 32. Magpie Crow Euploea radamanthus
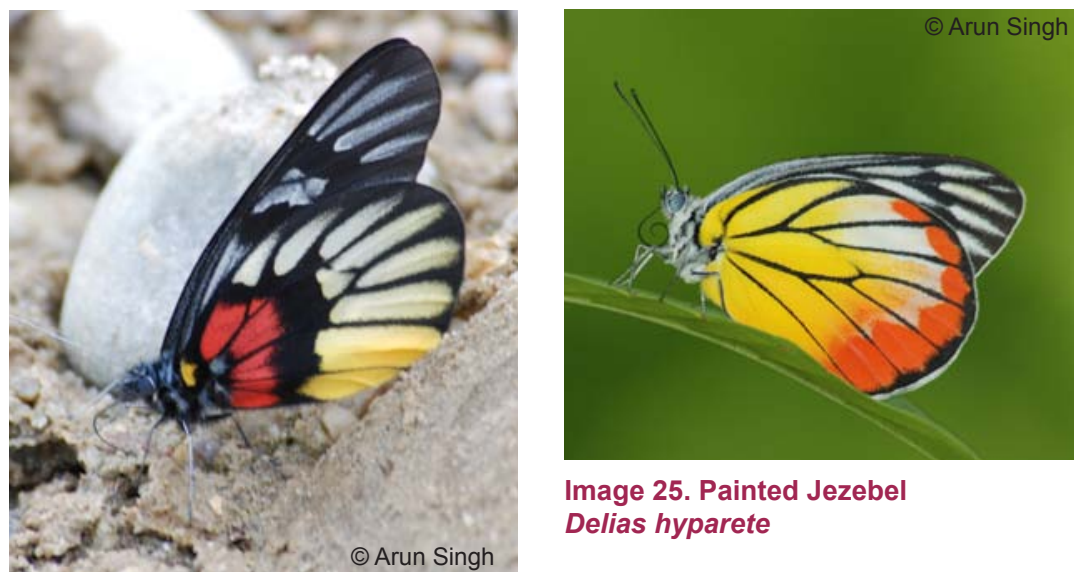

Image 25. Painted Jezebel Delias hyparete

Image 24. Red-breast Jezebe Delias thysbe

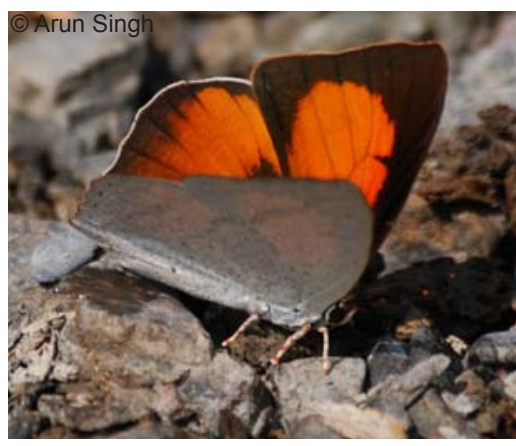

Image 27. Angled Sumbeam

Curetis acuta

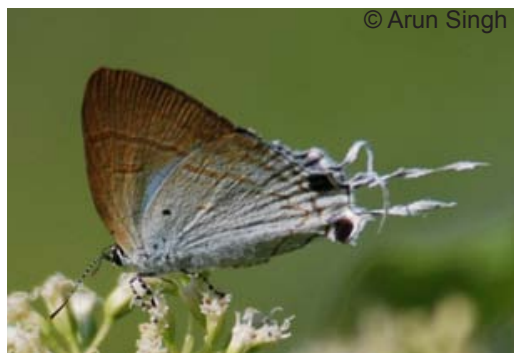

Image 30. Fluffy Tit Zeltus amasa

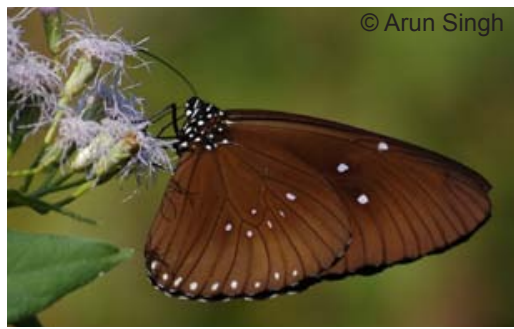

Image 33. Long-branded Crow Euploea algae deione

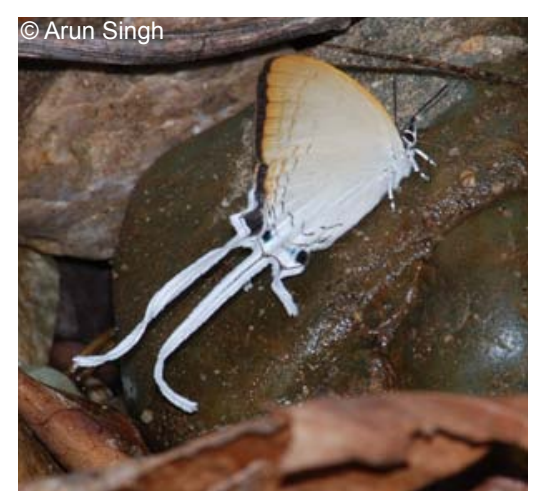

Image 28. Common Imperial Cheritra freja

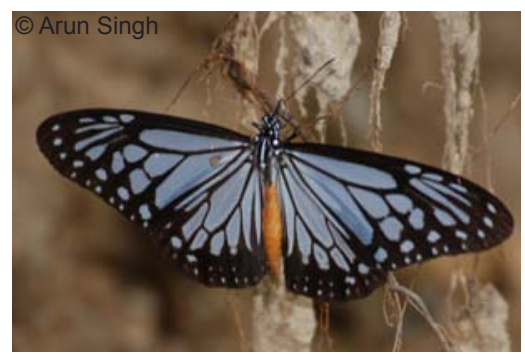

Image 31. Chocolate Tiger Parantica melaneus

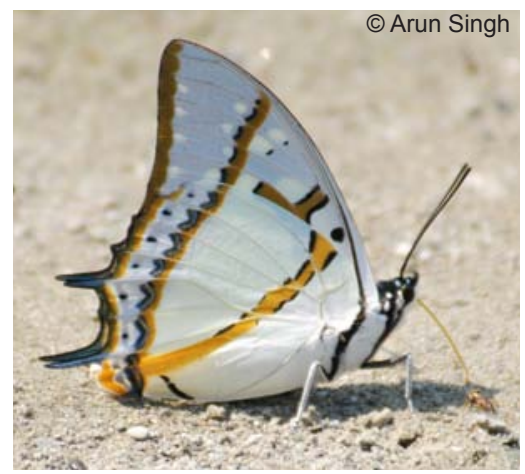

Image 34. Great Nawab Polyura eudamippus 


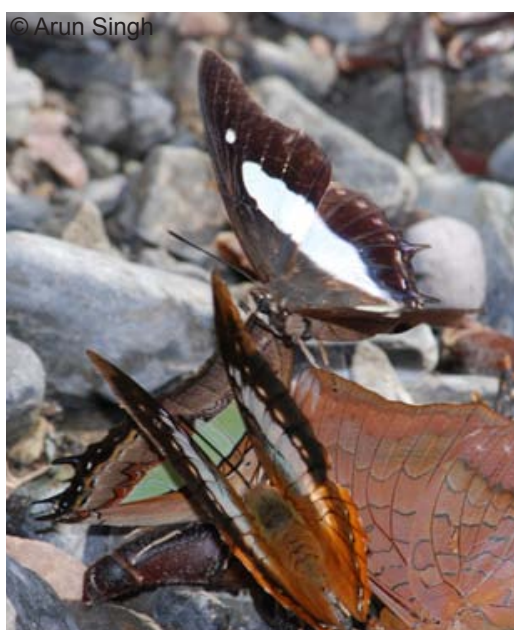

Image 35. Pallid Nawab Polyura arja

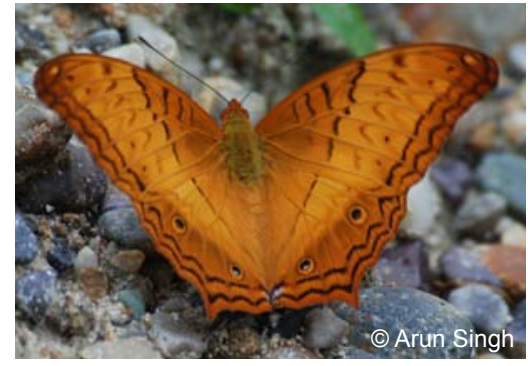

Image 38. Cruiser Vindula erota

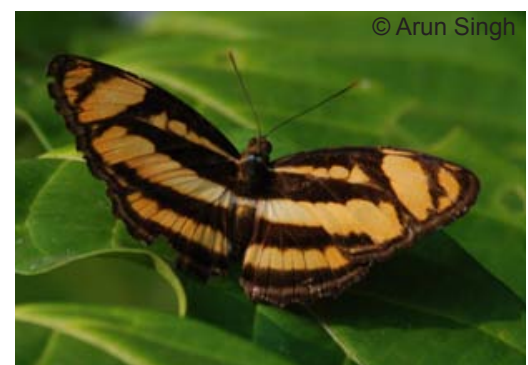

Image 41. Colour Sergeant Athyma nefte (male)

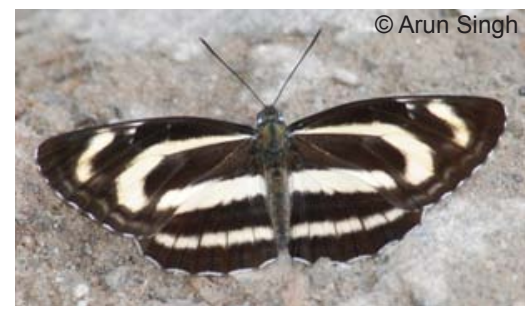

Image 44. Pale Hockey Stick Sailer Neptis manasa

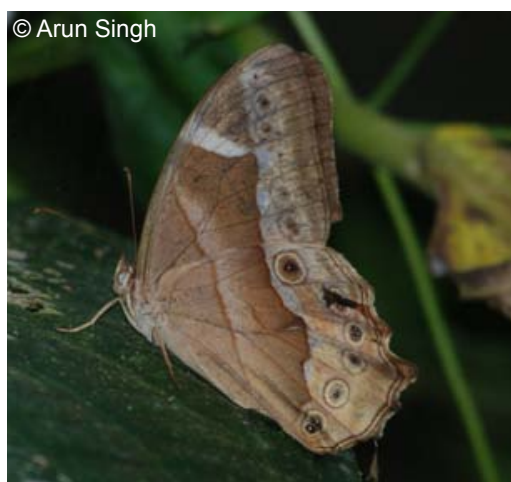

Image 36. Common Red Forester Lethe mekara

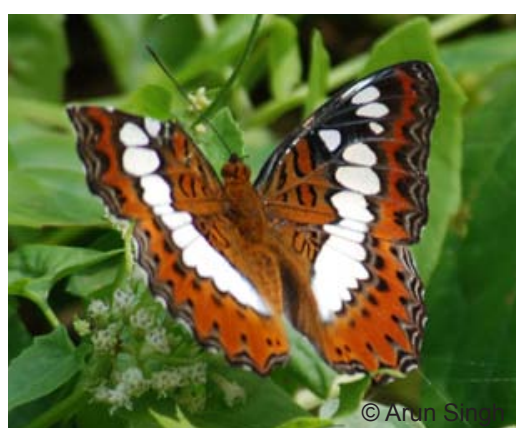

Image 39. Commander

Moduza procris

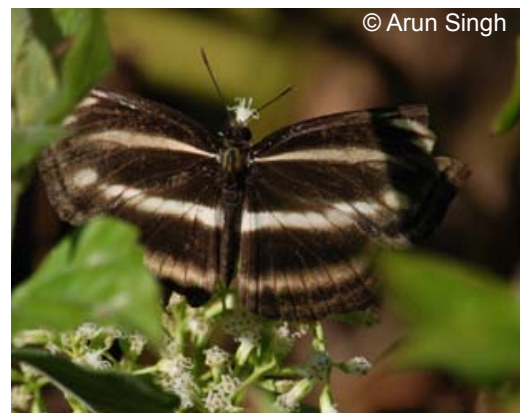

Image 42. Dingy Sailer

Neptis pseudovikasi

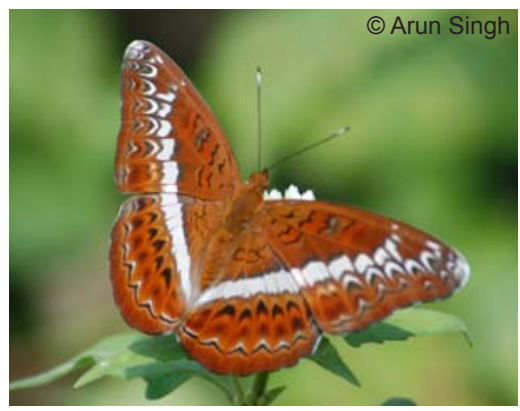

Image 45. Knight Lebadea martha

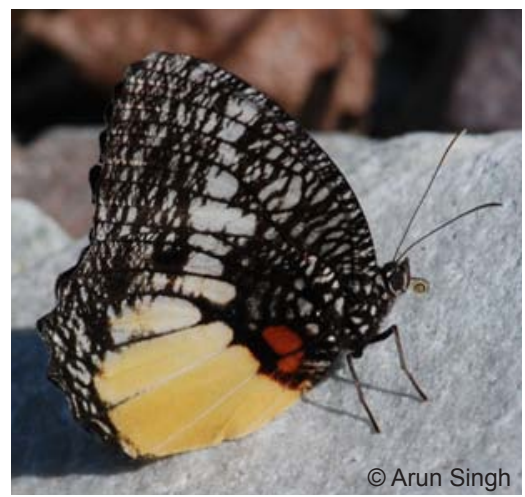

Image 37. Jezebel Palmfly

Elymnias vasudeva vasudeva

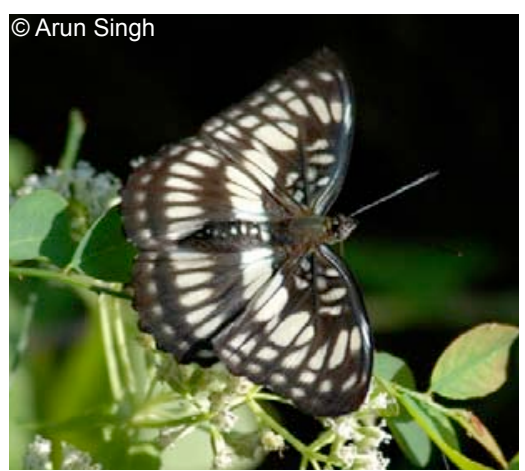

Image 40. Black Vein Sergeant

Athyma ranga (male)

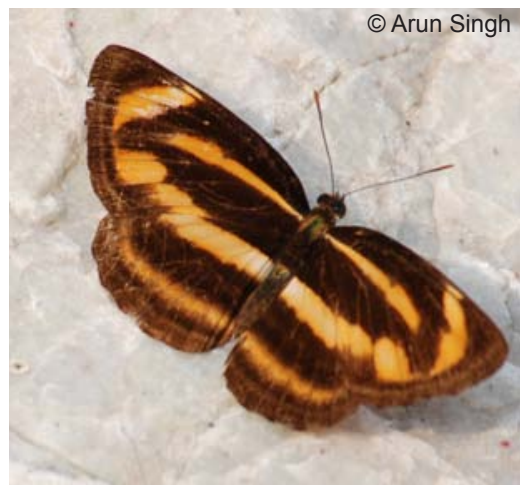

Image 43. Yellow Sailer Neptis ananta

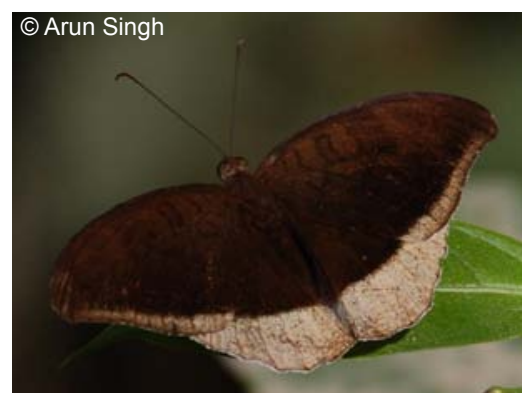

Image 46. Grey Count Tanaecia lepidea male 


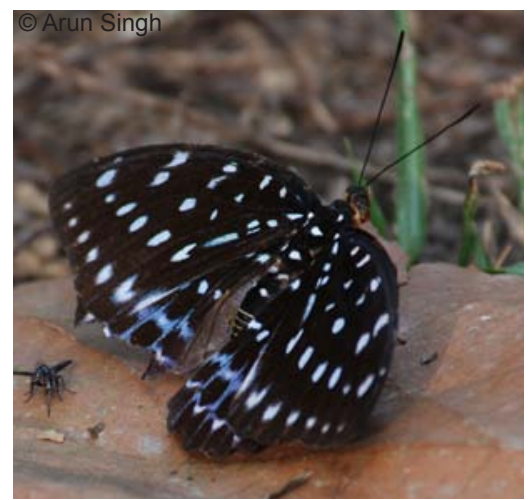

Image 47a. Dark Archduke

Lexias dirtea khasiana (female)

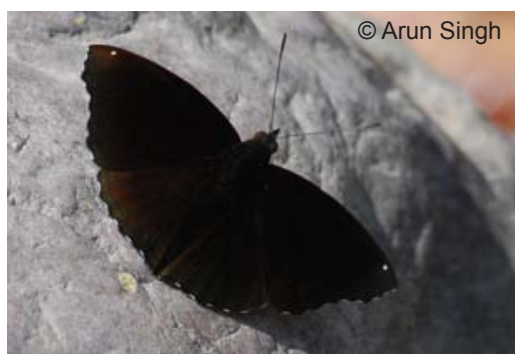

Image 49. Black Prince

Rohana parisatis (male)

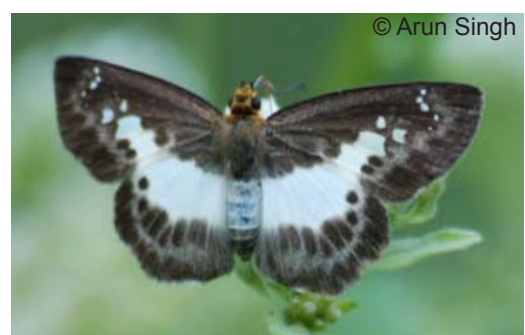

Image 52. Himalayan White Flat Seseria dohertyi

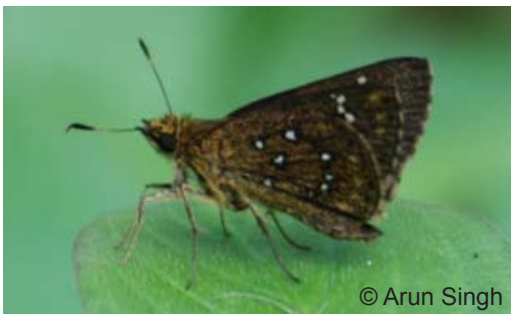

Image 55. Atkinson's Bob Arnetta atkinsoni

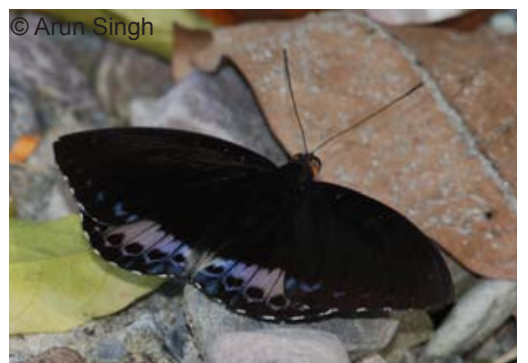

Image 47b. Dark Archduke Lexias dirtea khasiana (male)

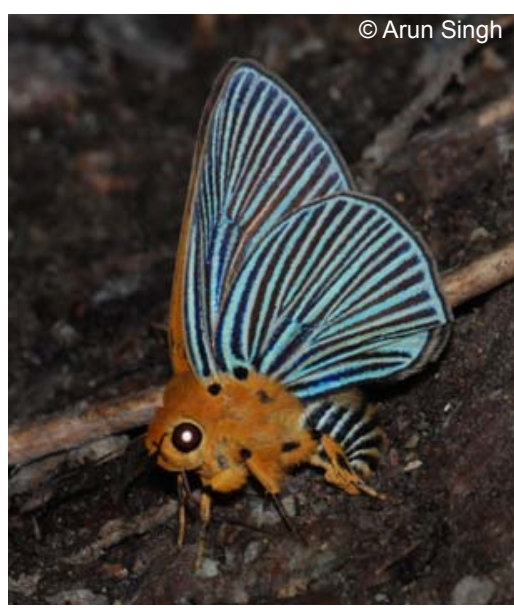

Image 50. Small Green Awlet Burala amara

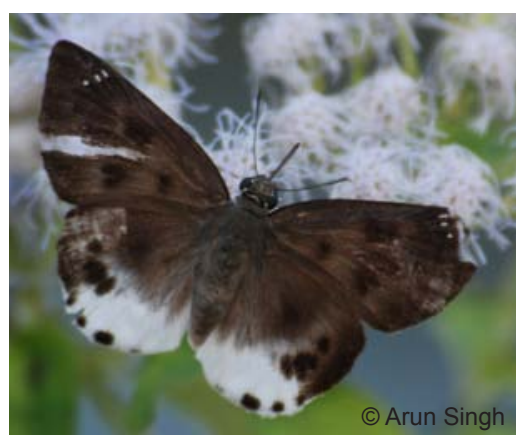

Image 53. Large Snow Flat Taigiades parra gala

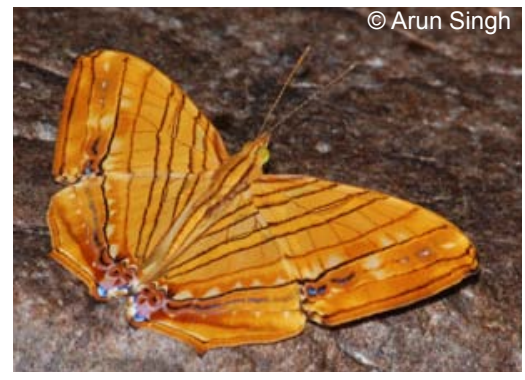

Image 48. Common Maplet Chersonesia risa

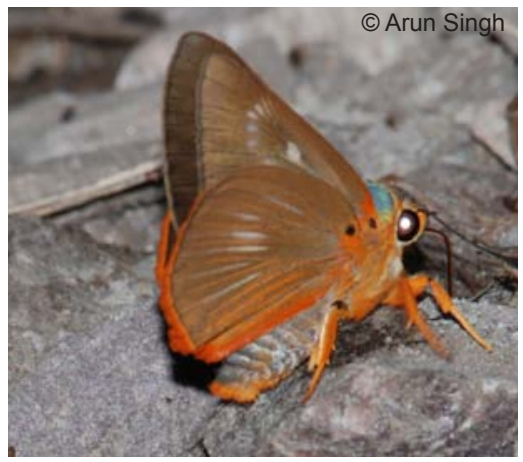

Image 51. Orange Awlet Burala jaina

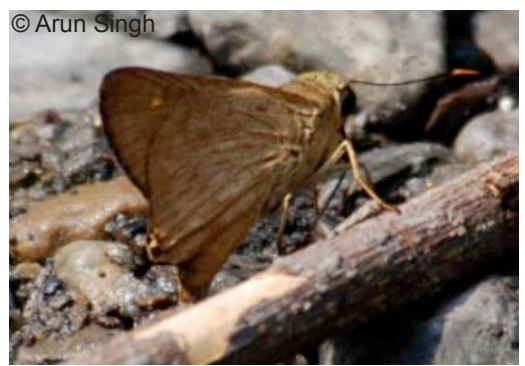

Image 54. Light Straw Ace

Pithauria straminiepennis

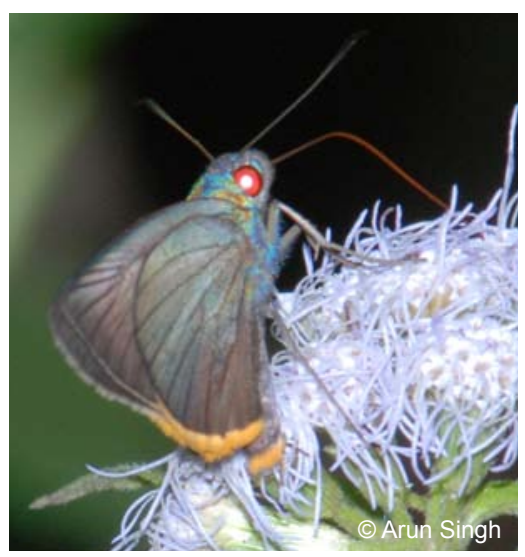

Image 56. Black-veined Redeye Matapa sasiarna 


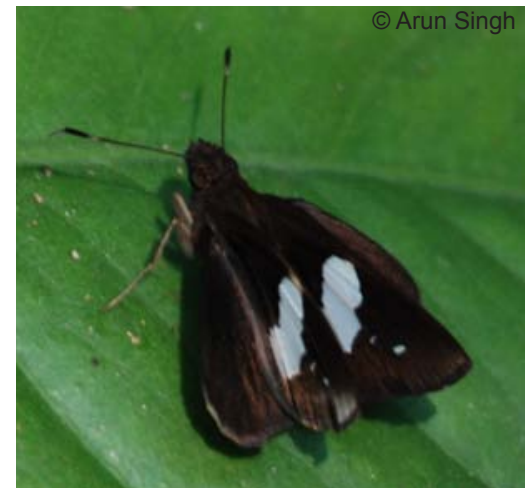

Image 57. Restricted Demon Notocrypta curvifascia

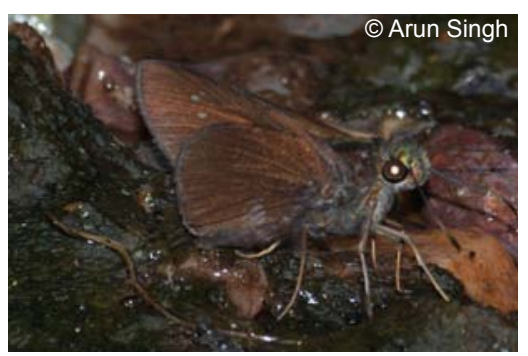

Image 58. Chocolate Demon Ancistroides nigrita a 'rare' species in India (Evans 1932).

\section{CONCLUSION}

High value of 'Simpson's index '(0.8929-0.9687) points to the area having high variation. A stretch of ca. $12 \mathrm{~km}$ monitored during the 18-day sampling revealed as many as 213 species and had the potential of adding many more species. The list provided here is in no way complete but represents ca. $2 / 3$ species found in these tracts in the study area and ca. $1 / 4$ of the species estimated from Bhutan. Besides, 12 taxa that are 'rare' in occurrence throughout their distribution range and worthy of conservation were also recorded in this subtropical lowland forest tract. Also, a good number of butterfly species were present during all the five seasons $(93 \pm 12$ species per season; range $=66-129$ species) which is a good indicator of the potential of this area for butterfly ecotourism, that needs to be explored. 'Biodiversity offsets' such as butterfly conservatories or even a butterfly park can be established here for conserving the 'rare' species and promoting ecotourism. Thus, the present study is a way forward to bridge the remaining gaps today in documenting the complete butterfly fauna of the area, identifying sites and species of conservation concerns in the subtropical lowland forests of Eastern Himalaya.

\section{REFERENCES}

Choudhury, K. (2010). Rediscovery of two rare butterflies Papilio elephenor Doubleday, 1845 and Shijimia moorei Leech, 1889 from proposed Ripu-Chirang Wildlife Sanctuary, Assam, India. Journal of Threatened Taxa 2(4): 831-834.

D'Abrera, B. (1982). Butterflies of the Oriental Region - Part I. Papilionidae, Pieridae \& Danaidae. Hill House, Victoria, Australia, 244pp.

D'Abrera, B. (1985). Butterflies of the Oriental Region-Part II. Nymphalidae, Satyridae \& Amathusiidae. Hill House, Victoria, Australia, 534pp.

D'Abrera, B. (1986). Butterflies of the Oriental RegionPart III. Lycaenidae \& Riodinidae. Hill House, Victoria, Australia, 672pp.

Simpson, E.H. (1949). Measurement of diversity. Nature 163: 688 (http://www.wku.edu/ smithch/biogeog/SIMP1949. $\mathrm{htm})$.

Evans, W.H. (1932). The Identification of Indian Butterflies2nd edition. Bombay Natural History Society, Bombay 464pp.

Haribal, M. (1992). The Butterflies of Sikkim Himalaya and their Natural History. Sikkim Nature Conservation Foundation, Sikkim, 217pp.

Inskipp, C., T. Inskipp \& R.Grimmette (1999). Birds of Bhutan. Timeless Books, New Delhi, 192pp.

IUCN (2010). IUCN Red List of Threatened Species. Version 2010.4. <www.iucnredlist.org>. Downloaded on 08 February 2011.

Kehimkar, I. (2008). The Book of Indian Butterflies. BNHS, Oxford University. Delhi Press, 497pp.

McAllister, D.E., J.F. Craig, N. Davidson, S. Delany \& M. Seddon (2001). Biodiversity Impacts of Large Dams. Background Paper Nr. 1. Prepared for IUCN/UNEP/ WCD, 1-68pp. (http://intranet.iucn.org/webfiles/doc/ archive/2001/IUCN850.PDF).

Mishra, G. (2009). Environmental Impact of large dams. In Dams, Structures and Water Resources LINK.

Singh, A.P. \& R.S. Bhandari (2003). Butterfly diversity in 
tropical moist deciduous sal (Shorea robusta) forests of Dehradun valley: the lower western Himalayas. Indian Forester 129(10): 1257-1269.

Singh, A.P. \& R. Pandey (2004). A model for estimating butterfly species richness of areas across the Indian subcontinent: species proportion of family papilionidae as an indicator. Journal of the Bombay Natural History Society 101: 79-89.

Smith, C. (1989). Butterflies of Nepal (Central Himalayas). Craftman Press Bangkok, 352pp.

Smith, C. (2006). Illustrated Checklist of Nepal's Butterflies.
Craftman Press, Bangkok, 129pp.

Sørensen, T.A. (1948). A method of establishing groups of equal amplitude in plant sociology based on similarity of species content, and its application to analyses of the vegetation on Danish commons. Kongelige Danske Videnskabernes Selskabs Biologiske Skrifter 5: 1-34.

van der Poel, P. \& T. Wangchuk (2007). Butterflies of Bhutan. Mountains, hills and valleys between 800-3000m. Royal Society for Protection of Nature (RSPN) Thimpu, Bhutan. Wynter-Blyth, M.A. (1957). Butterflies of the Indian Region. Bombay Natural History Society, Bombay, 523pp. 